\title{
Silymarin-Enriched Biostimulant Foliar Application Minimizes the Toxicity of Cadmium in Maize by Suppressing Oxidative Stress and Elevating Antioxidant Gene Expression
}

\author{
Hesham F. Alharby ${ }^{1}$, Hassan S. Al-Zahrani ${ }^{1}$, Khalid R. Hakeem ${ }^{1}{ }^{1}$, Hameed Alsamadany ${ }^{1}{ }^{(D}$, \\ El-Sayed M. Desoky ${ }^{2}$ iD and Mostafa M. Rady ${ }^{3, *(\mathbb{D})}$ \\ 1 Department of Biological Sciences, Faculty of Science, King Abdulaziz University, \\ 21589 Jeddah, Saudi Arabia; halharby@kau.edu.sa (H.F.A.); hsalzahrani@kau.edu.sa (H.S.A.-Z.); \\ kur.hakeem@gmail.com (K.R.H.); halsamadani@kau.edu.sa (H.A.) \\ 2 Botany Department, Faculty of Agriculture, Zagazig University, Zagazig 44519, Egypt; Sayed1981@zu.edu.eg \\ 3 Botany Department, Faculty of Agriculture, Fayoum University, Fayoum 63514, Egypt \\ * Correspondence: mmr02@fayoum.edu.eg
}

Citation: Alharby, H.F.; Al-Zahrani, H.S.; Hakeem, K.R.; Alsamadany, H.; Desoky, E.-S.M.; Rady, M.M.

Silymarin-Enriched Biostimulant

Foliar Application Minimizes the

Toxicity of Cadmium in Maize by

Suppressing Oxidative Stress and Elevating Antioxidant Gene

Expression. Biomolecules 2021, 11, 465.

https://doi.org/10.3390/

biom11030465

Academic Editor: Guzel Kudoyarova

Received: 21 February 2021

Accepted: 18 March 2021

Published: 21 March 2021

Publisher's Note: MDPI stays neutral with regard to jurisdictional claims in published maps and institutional affiliations.

Copyright: (C) 2021 by the authors Licensee MDPI, Basel, Switzerland. This article is an open access article distributed under the terms and conditions of the Creative Commons Attribution (CC BY) license (https:/ / creativecommons.org/licenses/by/ $4.0 /)$.
Abstract: For maize, the potential preventive role of foliar spraying with an extract derived from maize grain ( $\mathrm{MEg}, 2 \%)$, silymarin $(\mathrm{Sm}, 0.5 \mathrm{mM})$, or silymarin-enriched $\mathrm{MEg}$ (MEg-Sm) in attenuating the stress effects of cadmium $(\mathrm{Cd}, 0.5 \mathrm{mM})$ was examined using a completely randomized design layout. Under normal conditions, foliar spraying with MEg, Sm, or MEg-Sm was beneficial (with MEgSm preferred) for maize plants, whereas the benefit was more pronounced under Cd stress. The use of $\mathrm{Cd}$ through irrigation water decreased plant growth traits, photosynthetic efficiency, including instantaneous carboxylation efficiency, Fv / Fm, and pigment contents, and hormonal contents (e.g., auxin, gibberellins, cytokinins including trans-zeatin, and salicylic acid). These undesired findings were due to an increase in $\mathrm{Cd}$ content, leading to increased levels of oxidative stress $\left(\mathrm{O}_{2}{ }^{\bullet-}\right.$ and $\left.\mathrm{H}_{2} \mathrm{O}_{2}\right)$, ionic leakage, and lipid peroxidation. Therefore, this damage resulted in an increase in the activities of nonenzymatic antioxidants, Sm, antioxidative enzymes, and enzyme gene expression. However, under Cd stress, although foliar spray with MEg or Sm had better findings than control, MEgSm had better findings than MEg or Sm. Application of MEg-Sm greatly increased photosynthesis efficiency, restored hormonal homeostasis, and further increased the activities of various antioxidants, Sm, antioxidative enzymes, and enzyme gene expression. These desired findings were due to the suppression of the $\mathrm{Cd}$ content, and thus the levels of $\mathrm{O}_{2}{ }^{\bullet-}, \mathrm{H}_{2} \mathrm{O}_{2}$, ionic leakage, and lipid peroxidation, which were positively reflected in the growth and accumulation of dry matter in maize plants. The data obtained in this study recommend applying silymarin-enriched maize grain extract (MEg-Sm at $0.24 \mathrm{~g} \mathrm{Sm} \mathrm{L}^{-1}$ of MEg) as a spray solution to maize plants when exposed to excess Cd in soil or irrigation water.

Keywords: maize crop; performance; cadmium stress; antioxidant system; gene expression; plant extract; silymarin

\section{Introduction}

To maintain food security and crop productivity as well as to maintain sustainable agriculture, the accumulation of heavy metals on agricultural lands must be restricted. Crop plants must be qualified to cope with the adverse effects of heavy metals using novel strategies to minimize plant uptake or increase the plant's resistance to their massive damage. Farmland contaminated with heavy metals is causing a dangerous decline in the efficiency of processes in plants concerning growth and productivity [1-8]. The increase in heavy metals in the soil stimulates oxidative stress linked to the overproduction of ROSs (reactive species of oxygen radicals). ROSs threaten plants by endangering various pathways related to both physiobiochemistry and molecular biology [8-10]. The decrease in plant 
growth due to heavy metals depends on some factors, including plant species, heavy metal concentration, growth conditions, and experimental conditions [11,12]. Among various heavy metals, the highest toxic effect of cadmium $(\mathrm{Cd})$-related pollution has been observed in wheat $[1,3,6,10]$, pea [13], and rice $[8,14]$.

Agricultural land and the plants cultivated on it have become severely threatened due to Cd toxicity worldwide [4,15]. Even with low concentrations, $\mathrm{Cd}$ is harmful to crop plants, and thus harmful to humans and animals that feed on these Cd-contaminated plants. After being absorbed by the root system of the plant, Cd easily transports into the shoot and adversely influences plant morphology and physiobiochemistry during all stages of the plant life cycle (e.g., germination, vegetative growth, and fruiting stages) [16]. The usual symptoms common to plants are stunted root and shoot, chlorosis of leaves, and a sharp decrease in biomass accumulation, all of which ultimately lead to plant death [9-16]. Cd accumulation greatly affects the absorption and transportation of almost all key nutrients in different parts of the plant [17-19]. These adverse events, particularly concerning the interference between the $\mathrm{Cd}$ metal and essential nutrients, can be attributed to the channel competition for nutrient uptake occurring at the molecular level [18].

Often, the endogenous antioxidant defense system is not sufficient for the plant to defend against environmental foes, including $\mathrm{Cd}$. Thus, a plant extract known to be a biostimulant, such as maize grain extract (MEg), can be used as a foliar spray and/or seed priming solution to support plants to increase their tolerance to environmental opponents [3,20-23], including Cd stress [3].

Presently, MEg has been used to enhance plant efficiency under different stress conditions, including Cd stress, as it is an essential organic biostimulator rich in many growthpromoting substances for different stressed plants, such as antioxidants, phytohormones, and essential nutrients [3]. After applying MEg, plant morphology, physiology, and biochemistry have been positively modified along with stimulation of plant tolerance against damage of some stresses [3,20-23]. Therefore, MEg is a potent novel biostimulator to give stressed plants the power to resist damage from environmental opponents.

Among the most essential crops around the world, maize (Zea mays L.) is ranked third after wheat and rice. In developing countries, Zea mays is one of the key dietary food components because of its high nutritional value [24]. Due to the increasing environmental opponents caused by climate change, and the rapid and turbulent growth of industries and demographics, the yield of Zea mays is decreasing worldwide, and the issue has been exacerbated by the arrival of $\mathrm{Cd}$ in humans and animals [25], thus toxicity from $\mathrm{Cd}$ in Zea mays is a major concern.

As found in the preliminary study of the current investigation (Table S1), Zea mays (as a $\mathrm{C}_{4}$ crop) is more sensitive to $\mathrm{Cd}$ and more responsive to $\mathrm{MEg}$ than other species such as wheat [3], so it was selected for the present study. There are no investigations on the influences of MEg and Cd on Zea mays; however, only one paper has been published dealing with the influences of MEg and Cd, but it focused on Triticum aestioum [3]. To date, no investigations have been conducted with silymarin ( $\mathrm{Sm})$-enriched $\mathrm{MEg}(\mathrm{MEg}+\mathrm{Sm})$ for Zea mays grown under Cd stress. Therefore, this is the first investigation in which $\mathrm{MEg}+\mathrm{Sm}$ was applied to leaves to encourage the growth of Zea mays under Cd stress. MEg lacks silymarin, so MEg was enriched with silymarin for this study.

This investigation was, therefore, aimed at studying the influences of $\mathrm{MEg}+\mathrm{Sm}$ on plant growth, physiobiochemistry, enzyme activities, and enzyme-related gene expressions in Cd-stressed Zea mays. To fulfill this hypothesis, a set of morphophysiobiochemical and molecular indices was identified to investigate $\mathrm{MEg}+\mathrm{Sm}$-induced stress tolerance to $\mathrm{Cd}$ in Zea mays.

\section{Materials and Methods}

\subsection{Plant Material, Experimental Description, and Layout}

Maize seeds (cv. Hybrid 306) were secured from the ARC (Agricultural Research Center), Egypt. A 1\% solution of sodium oxychloride ( $\mathrm{NaOCl}, 5 \%)$ was used to sterilize 
the seed surface for $2 \mathrm{~min}$, and distilled water was then utilized to thoroughly wash the seeds. Using sterilized Petri dishes (12 $\mathrm{cm}$ in diameters), the sterilized seeds were germinated using moistened filter papers at $20^{\circ} \mathrm{C}$ under $16 \mathrm{~h} / 8 \mathrm{~h}$ light/darkness for 7 days. Five germinated seedlings were carefully transplanted in each pot filled with $10 \mathrm{~kg}$ of ion-free sand moistened with a nutrient solution. As detailed in [26], the composition of the nutrient solution used for watering Zea mays is presented in Table 1. Every other day, watering was applied to the seedlings with this nutrient solution.

Table 1. The nourishing solution composition prepared for watering maize seedlings.

\begin{tabular}{ccc}
\hline The Chemical Substance & The Chemical Formula & The Amount $(\boldsymbol{\mu M})$ \\
\hline Calcium nitrate & $\mathrm{Ca}\left(\mathrm{NO}_{3}\right)_{2}$ & 2000 \\
\hline Potassium sulfate & $\mathrm{K}_{2} \mathrm{SO}_{4}$ & 700 \\
\hline Magnesium sulfate & $\mathrm{MgSO}_{4}$ & 500 \\
\hline Monopotassium phosphate & $\mathrm{KH}_{2} \mathrm{PO}_{4}$ & 100 \\
\hline Potassium chloride & $\mathrm{KCl}$ & 100 \\
\hline Boric acid & $\mathrm{H}_{3} \mathrm{BO}_{3}$ & 1 \\
\hline Manganese sulfate & $\mathrm{MnSO}_{4}$ & 1 \\
\hline Copper sulfate & $\mathrm{CuSO}_{4}$ & 0.25 \\
\hline Ammonium molybdate & $\left(\mathrm{NH}_{4}\right)_{6} \mathrm{Mo}_{7} \mathrm{O}_{24}$ & 0.01 \\
\hline Fe-ethylenediaminetetraacetic acid (EDTA) & $\left.\left(\mathrm{OOCCH}_{2}\right)_{2} \mathrm{NCH}_{2} \mathrm{CH}_{2} \mathrm{NCCH}_{2} \mathrm{COO}\right)_{2} \mathrm{FeNa} \times \mathrm{H}_{2} \mathrm{O}$ & 100 \\
\hline
\end{tabular}

Thinning into three seedlings of similar size per pot was implemented after four irrigation times. The following controlled conditions were applied for seedling growth: Photon flux of $390 \mathrm{mE} \mathrm{m}^{-2} \mathrm{~s}^{-1}$ at plant height with dark/light regime $14 / 10 \mathrm{~h}$ at $20 / 24{ }^{\circ} \mathrm{C}$ was applied under a relative humidity of $65-70 \%$.

Cadmium (Cd; Sigma-Aldrich, St. Louis, MO, USA) treatment was started two weeks after transplantation. The cadmium was applied to plants at a concentration of $0.5 \mathrm{mM}$ using cadmium sulfate $\left(\mathrm{CdSO}_{4}\right)$ with the nutrient solution added to the seedlings every other day. The $0.5 \mathrm{mM} \mathrm{Cd}$ was selected for the main study based on our initial study. It was found that 15 irrigation times applied throughout the experiment with $0.5 \mathrm{mM} \mathrm{Cd}$ had the most damage to the maize plants, whereas 15 irrigation times with a concentration of more than $0.5 \mathrm{mM}$ killed the plants (Table S1). Foliar spraying with maize grain extract (MEg), silymarin (Sm; Sigma-Aldrich, St. Louis, MO, USA), or silymarin-enriched MEg was implemented on the seedlings one week after the first watering with Cd-containing nutrient solution. The concentrations applied were $2 \%, 0.5 \mathrm{mM}$, or $0.24 \mathrm{~g} \mathrm{Sm} \mathrm{L}^{-1}$ of $\mathrm{MEg}$, respectively. Two more foliar sprays were performed one week and two weeks later. Depending on our initial study, the concentrations of MEg and Sm used for this study were also nominated, as these concentrations conferred the best preferable responses (Table S1). To increase the penetration efficiency of the spray solution, Tween-20 was used a few drops at a time as a surfactant. The Optima 3300DV ICP-MS instrument (Perkin-Elmer, Inductively Coupled Plasma, Waltham, Mass Spectrometer, MA 02451, USA) was utilized to maintain the $\mathrm{Cd}$ concentration at $0.5 \mathrm{mM}$ by continuous measurement. The trials were terminated one month after the first $\mathrm{Cd}$ application. Eight treatments were applied for this study and are presented in Table 2. A completely randomized design (CRD) was used to arrange the experimental pots. 
Table 2. The experimental treatment description.

\begin{tabular}{|c|c|}
\hline Treatment & Description \\
\hline Control & There is no stress and no foliar applications \\
\hline $\mathrm{Sm}$ & Foliar spray with $0.5 \mathrm{mM}$ silymarin \\
\hline MEg & Foliar spray with $2 \%$ maize grain extract \\
\hline MEg-Sm & $\begin{array}{c}\text { Foliar spray with maize grain extract enriched } \\
\text { with silymarin }\left(0.24 \mathrm{~g} \mathrm{Sm} \mathrm{L}^{-1} \text { of } \mathrm{MEg}\right)\end{array}$ \\
\hline $\mathrm{Cd}^{2+}$ & $\begin{array}{l}\text { Watering the maize seedlings with a } \\
\text { nourishing solution containing } 0.5 \mathrm{mM} \mathrm{Cd}^{2+}\end{array}$ \\
\hline $\mathrm{Cd}^{2+}+\mathrm{Sm}$ & $\begin{array}{l}\text { Watering the maize seedlings with a } \\
\text { nourishing solution containing } 0.5 \mathrm{mM} \mathrm{Cd}^{2+}+ \\
\text { foliar spray with } 0.5 \mathrm{mM} \text { silymarin }\end{array}$ \\
\hline $\mathrm{Cd}^{2+}+\mathrm{MEg}$ & $\begin{array}{l}\text { Watering the maize seedlings with a } \\
\text { nourishing solution containing } 0.5 \mathrm{mM} \mathrm{Cd}^{2+}+ \\
\text { foliar spray with } 2 \% \text { maize grain extract }\end{array}$ \\
\hline $\mathrm{Cd}^{2+}+\mathrm{MEg}-\mathrm{Sm}$ & $\begin{array}{l}\text { Watering the maize seedlings with a } \\
\text { nourishing solution containing } 0.5 \mathrm{mM} \mathrm{Cd}^{2+}+ \\
\text { foliar spray with maize grain extract enriched } \\
\text { with silymarin }\left(0.24 \mathrm{~g} \mathrm{Sm} \mathrm{L}^{-1} \text { of } \mathrm{MEg}\right)\end{array}$ \\
\hline
\end{tabular}

\subsection{Preparations of Maize Grain Extract (MEg) and Silymarin (Sm) Solutions}

The full method outlined in $[3,23]$ was utilized to prepare an extract from maize grain (MEg) selecting the local genotype of Egyptian Zea mays. The grains were covered with wet cotton and a clean piece of cloth and kept until soft and then transferred for milling using enough distilled water. Then, the mixture was filtered under a vacuum. Black bottles were used to keep the filtrate undercooling $\left(4^{\circ} \mathrm{C}\right)$. The remaining residue was utilized to obtain an alcoholic extract by extraction with methanol (70\%) for 3 days. Again, filtration was performed. Using a rotary evaporator, the filtrate was evaporated until the alcohol was completely removed. Both extracts (e.g., the alcoholic and aqueous) were mixed well; then, the mixture was concentrated to reach the target concentrations. Note: It is preferable to use the extract immediately, otherwise it will be kept under freezing $\left(-20^{\circ} \mathrm{C}\right)$ until use.

Some major ingredients in MEg were detected. For free proline [27], ascorbate [28], and glutathione [29], the contents were determined in MEg, and Sm content was then determined according to the methods detailed in [30,31]. DPPH-radical scavenging activity was assayed to specify the antioxidative activity in MEg using the 1,1-diphenyl-2picrylhydrazyl [32]. The fresh extract was used for endogenous levels of phytohormones (e.g., auxins, gibberellins, cytokinins, including zeatin-type-cytokinins). The sample was frozen in liquid $\mathrm{N}$ for preparing to extract different phytohormones that were then analyzed using the GC/MS system [33]. The results of all assessments are shown in Table 3. As shown, the content of Sm detected in MEg was low $\left(0.02 \mu \mathrm{g} \mathrm{g}^{-1} \mathrm{FW}\right)$, and thus MEg at $\%$ level was enriched with $\mathrm{Sm}$ by adding it at a concentration of $0.5 \mathrm{mM}$ (i.e., $0.24 \mathrm{~g} \mathrm{Sm} \mathrm{L}^{-1}$ of MEg). 
Table 3. The antioxidant and hormonal contents in maize grain extract (MEg).

\begin{tabular}{ccc}
\hline Component & Unit & Value \\
\hline & The antioxidative compounds: & $24.66 \pm 0.39$ \\
Free proline & & $14.26 \pm 0.07$ \\
Ascorbic acid (AsA) & $\left(\mu \mathrm{mol} \mathrm{g}^{-1} \mathrm{FW}\right)$ & $8.85 \pm 0.03$ \\
Glutathione (GSH) & $\left(\mu \mathrm{g} \mathrm{g}^{-1} \mathrm{DW}\right)$ & $0.02 \pm 0.00$ \\
Silymarin (Sm) & $\%$ & $89.22 \pm 1.62$ \\
DPPH radical-scavenging activity & Phytohormones: & $2.74 \pm 0.05$ \\
Indole-3-acetic acid (IAA) & & $2.58 \pm 0.04$ \\
Gibberellic acid 1 (GA $)$ & $2.75 \pm 0.06$ \\
Gibberellic acid 3 (GA $)$ & & $3.96 \pm 0.08$ \\
Total cytokinins (CKs) & & $2.55 \pm 0.04$ \\
Trans-Zeatin $(t-Z)$ & & $2.89 \pm 0.05$ \\
Salicylic acid (SA) & & \\
\hline
\end{tabular}

Values presented in the table are means $(n=3$ for all measures $) \pm$ standard error.

\subsection{Maize Morphological Traits}

A large graduated ruler was utilized to record plant height (from the surface level of the soil to the end of the first upper leaf in $\mathrm{cm}$ ). After counting the leaves on each plant, all green leaves per plant were scanned utilizing a Stationary Leaf Area Meter LI-3100C (LI-COR, Lincoln, NE, USA) to record the total leaves area per plant. The shoot of each plant was weighed to record its fresh weight, and after oven-drying at $70^{\circ} \mathrm{C}$, the shoot dry weight was recorded per plant after at least two constant dry weights.

\subsection{Leaf Photosynthetic Efficiency}

Using the first fully expanding upper leaf on each plant, detailed procedures in [34-36] were applied for assessing the instantaneous efficiency of carboxylation (iEC; $\mu \mathrm{mol} \mathrm{m}{ }^{-2}$ $\mathrm{s}^{-1}$ ), photosynthetic pigment contents $\left(\mathrm{mg} \mathrm{g}^{-1} \mathrm{FW}\right)$, and photochemical activity (using potassium cyanide technique), respectively.

The fluorescence measurements of chlorophyll $a$ were made utilizing a modulated fluorometer (PAM-2000, Heinz-Walz). The measurements were made using the saturation pulse method [34] on leaves preadapted to the dark in a growth chamber $\left(12 \mathrm{~h}\right.$ at $28^{\circ} \mathrm{C}$ and $70 \%$ relative humidity). The potential quantum efficiency of photosystem II (FSII) $F_{v} / F_{m}$ ( $F_{v}$ is the variable fluorescence $\left(F_{v}=F_{m}-F_{0}\right), F_{0}$ is the initial fluorescence, and $F_{m}$ is the maximum fluorescence values) was measured. After fluorescence measurements, the plants remained in the growth chamber for two hours, under the following conditions: $28^{\circ} \mathrm{C}$, $350 \mu \mathrm{mol} \mathrm{m} \mathrm{m}^{-2} \mathrm{~s}^{-1}$ of flow density photosynthetically active photons (DFFFA), $70 \%$ relative humidity. Then, the measures of net $\mathrm{CO}_{2}$ assimilation rate and internal concentration of $\mathrm{CO}_{2}$ with a system of portable photosynthesis ( $\mathrm{LCi}, \mathrm{ADC}$ ) in sheets submitted to DFFFA of $900 \mu \mathrm{mol} . \mathrm{m}^{-2} \cdot \mathrm{s}^{-1}$ supplied by a halogen lamp. The iEC was calculated as follows [34]:

$$
\mathrm{iEC}=\text { assimilation rate/internal concentration of } \mathrm{CO}_{2}
$$

Total chlorophyll and carotenoids were extracted with dimethyl sulfoxide and the absorbances were read at 480, 649, and $665 \mathrm{~nm}$ utilizing a Mullikan GO plate reader (Thermo Fisher Scientific; Waltham, MA, USA) [35]. For photochemical activity, chloroplast fragments from Zea mays were prepared and stored in a potassium chloride-sucrose medium. Fragments were incubated at $2{ }^{\circ} \mathrm{C}$ in sealed tubes at $\mathrm{pH} 6.8$ in the presence of different concentrations of potassium cyanide. At intervals, $1 \mathrm{~mL}$ samples were removed and the Hill reaction activity was measured at $10{ }^{\circ} \mathrm{C}$ using a potentiometric method [36]. 


\subsection{Oxidative Stress Biomarker Levels and Their Damage in Maize Plants}

Using the first fully expanding upper leaf on each plant, the detailed procedures in [37-39] were applied for assessing the levels of $\mathrm{O}_{2}{ }^{\bullet-}\left(\mathrm{A}_{580} \mathrm{~g}^{-1} \mathrm{FW}\right), \mathrm{H}_{2} \mathrm{O}_{2}$, and MDA $\left(\mu \mathrm{mol} \mathrm{g}{ }^{-1} \mathrm{FW}\right)$, respectively.

For determining $\mathrm{O}_{2}{ }^{\bullet}$, the content $\left(\mu \mathrm{mol} \mathrm{g}{ }^{-1} \mathrm{FW}\right)$ was evaluated using sample fragments $(1 \times 1 \mathrm{~mm}, 0.1 \mathrm{~g})$ that flooded using a $10 \mathrm{mM} \mathrm{K-phosphate} \mathrm{buffer} \mathrm{(pH} \mathrm{7.8);} \mathrm{each} \mathrm{of}$ them were mixed with each of NBT $(0.05 \%)$ and $\mathrm{NaN}_{3}(10 \mathrm{mM})$ for $1 \mathrm{~h}$ at room temperature. The mixture was heated for $0.25 \mathrm{~h}$ at $85^{\circ} \mathrm{C}$. The mixture was then cooled rapidly. The absorbance readings were taken at $580 \mathrm{~nm}$ [37]. For determining $\mathrm{H} 2 \mathrm{O} 2$ level $(\mu \mathrm{mol}$ per g of leaf $\mathrm{FW}), 0.25 \mathrm{~g}$ fresh leaf was homogenized in $5 \mathrm{~mL} 5 \%$ TCA. Homogenate centrifugation $(12,000 \times g)$ was performed at $4{ }^{\circ} \mathrm{C}$ for $15 \mathrm{~min}$. After collecting the supernatant, it was added to a reaction medium, $10 \mathrm{mM}$ of buffer (potassium phosphate, $\mathrm{pH} 7.0$ ) $+1 \mathrm{M}$ of KI. Using a spectrophotometer, the absorbance reading was recorded at $390 \mathrm{~nm}$ using a standard prepared from $\mathrm{H}_{2} \mathrm{O}_{2}$ [38]. Peroxidation of lipids was assessed by determining the level of malondialdehyde (MDA; $\mu \mathrm{mol}$ per $\mathrm{g}$ of leaf FW). MDA assessment was performed using the same $\mathrm{H}_{2} \mathrm{O}_{2}$ extracts. The calculation was performed with $0.155 \times 10^{-3} \mathrm{M}^{-1} \mathrm{~cm}^{-1}$ as a coefficient of molar extinction to record the content of MDA [39].

Total ions seeped from leafy tissue were measured depending on the method depicted in [40]. Electrical conductivities $\left(\mathrm{EC}_{1}, \mathrm{EC}_{2}\right.$, and $\mathrm{EC}_{3}$ ) of 20-leafy tissue disc solution were recorded three times-pre-heating, after 30-min heating at $45-55^{\circ} \mathrm{C}$, and after $10 \mathrm{~min}$ of boiling $\left(100{ }^{\circ} \mathrm{C}\right)$, respectively. Using a known formula, EL was computed:

$$
\operatorname{EL}(\%)=\left[\left(\mathrm{EC}_{2}-\mathrm{EC}_{1}\right) / \mathrm{EC}_{3}\right] \times 100
$$

\subsection{Determination of $\mathrm{Cd}$ Content}

Using the first fully expanding upper leaf on each plant, Cd content $\left(\mathrm{mg} \mathrm{kg}^{-1}\right.$ leaf dry weight) was analyzed using an atomic absorption spectrophotometer (Perkin-Elmer, Model 3300) [41]. After drying, a sample of $0.1 \mathrm{~g}$ was digested using an acidic mixture (e.g., $2 \mathrm{~mL}$ perchloric acid, $80 \%+10 \mathrm{~mL} \mathrm{H}_{2} \mathrm{SO}_{4}$, concentrated) for $12 \mathrm{~h}$. After dilution of the digested sample to reach $100 \mathrm{~mL}$ with distilled water, $\mathrm{Cd}^{2+}$ was measured.

\subsection{Determination of Antioxidant Contents and Redox State}

Using the first fully expanding upper leaf on each plant, the methods detailed in [27-29] were practiced for assessing proline content ( $\left.\mu \mathrm{mol} \mathrm{g}^{-1} \mathrm{DW}\right)$, AsA content ( $\left.\mu \mathrm{mol} \mathrm{g}{ }^{-1} \mathrm{FW}\right)$ and AsA redox state, and GSH content $\left(\mu \mathrm{mol} \mathrm{g}^{-1} \mathrm{FW}\right)$ and GSH redox state, respectively.

The method detailed by Bates et al. [27] was followed to determine the leaf content of free proline. After extraction of $0.5 \mathrm{~g}$ of fresh leaf sample using $3 \%, v / v$, sulphosalicylic acid and centrifugation at $10,000 \times g$ for $10 \mathrm{~min}, 2 \mathrm{~mL}$ supernatant was mixed with $2 \mathrm{~mL}$ solution of freshly prepared acid ninhydrin. The mixture was incubated in a water bath at $90{ }^{\circ} \mathrm{C}$ for $30 \mathrm{~min}$. The reaction was terminated in an ice bath and the mixture was then extracted again by mixing with $5 \mathrm{~mL}$ toluene. The mixture was separated in the dark for $20 \mathrm{~min}$ at room temperature. The toluene phase was collected and its absorbance was read at $520 \mathrm{~nm}$.

The Kampfenkel and Van Montagu [28] method was applied to estimate AsA level ( $\mu \mathrm{mol}$ per $\mathrm{g}$ of leaf $\mathrm{FW}$ ). The mixture of $30 \mathrm{mM}$ of buffer (potassium phosphate, $\mathrm{pH}$ 7.4) + TCA $(2.5 \%)+$ phosphoric acid $(8.4 \%)+$ bipyridyl $(0.8 \%)+$ ferric chloride $(0.3 \%)$ was received leaf extract. The reaction was conducted $\left(40{ }^{\circ} \mathrm{C}, 30 \mathrm{~min}\right)$, and absorbance was read at $525 \mathrm{~nm}$. Content of AsA + DHA (oxidized AsA) was assessed after the addition of extract to $500 \mu \mathrm{M}$ of DTT to estimate total AsA reduction by reading the absorbance on $525 \mathrm{~nm}$ and L-AsA was used as a standard, and the following formula was used to record AsA redox state:

$$
\text { AsA redox state }(\%)=[\mathrm{AsA} /(\mathrm{AsA}+\mathrm{DHA})] \times 100
$$


The Griffith [29] method was applied to assess the levels ( $\mu$ mol per g of leaf FW) of reduced GSH and the total (GSH + GSSG). For GSH assessment, extract of leaf +0.13 $\mathrm{M}$ of buffer (sodium phosphate, $\mathrm{pH} 7.4$ ) $+0.007 \mathrm{M}$ of buffer (sodium phosphate, $\mathrm{pH} 6.8$ ) $+0.006 \mathrm{M}$ of 5,5-dithiobis-(2-nitrobenzoic acid) (DTNB) as a reaction mixture was stayed on $30{ }^{\circ} \mathrm{C}$ for $10 \mathrm{~min}$. Then, absorbance reading was taken on $412 \mathrm{~nm}$. Total GSH level was determined after reducing GSSG to GSH by adding leaf extract to $0.13 \mathrm{M}$ of buffer (sodium phosphate, $\mathrm{pH} 7.4)+1 \mathrm{U}$ of GSH-reductase. The absorbance was read on $412 \mathrm{~nm}$. Content of GSH, as well as GSH+GSSG, was assessed along with a standard (GSH), and calculation of GSH redox state was done:

$$
\mathrm{GSH} \text { redox state } \%=[\mathrm{GSH} /(\mathrm{GSH}+\mathrm{GSSG})] \times 100
$$

\subsection{Determination of Silymarin (Sm) Content}

The Sm content was determined as detailed in [30,31]. The leaf sample (the first fully expanding upper leaf on each plant) was extracted for Sm using a Soxhlet apparatus. For extraction, methanol $(200 \mathrm{~mL})$ was used and the extract was then evaporated to dryness. The resulted sample was reconstituted in HPLC grade methanol $(25 \mathrm{~mL})$, and the reconstituted sample was diluted with methanol to assess Sm content $\left(\mu \mathrm{g} \mathrm{g}^{-1} \mathrm{DW}\right)$ using the HP 1100 Liquid Chromatograph (Thermo Fisher Scientific; Waltham, MA, USA).

\subsection{Phytohormone Analysis}

Using the first fully expanding upper leaf on each plant, the level of phytohormones was assessed using the HPLC apparatus. After extraction and centrifugation of each leaf sample, leaf debris was found between two formed phases. After concentration and resolubilization of the lower layer, injection into the apparatus column was performed for analysis. The separation was carried out for IAA, $\mathrm{GA}_{1}, \mathrm{GA}_{3}$, and trans-zeatin using $\mathrm{MeOH}[33]$.

\subsection{Enzymatic Antioxidant Activities Assaying and Molecular Study}

In an ice bath, $500 \mathrm{mg}$ of fresh leaf tissue was pulverized while using $10 \mathrm{~mL}$ of $50 \mathrm{mM}$ K-phosphate buffer $\left(\mathrm{K}_{2} \mathrm{HPO}_{4}+\mathrm{KH}_{2} \mathrm{PO}_{4}\right.$, Merck, Germany, $\mathrm{pH}$ 7.8). Centrifugation was practiced for the mixture at $10,000 \times g$ at $4{ }^{\circ} \mathrm{C}$ for $15 \mathrm{~min}$. The extract protein concentration was determined based on the method of Bradford [42]. SOD (EC 1.15.1.1) activity assay was done as detailed in Kono's [43] method. Sodium carbonate $\left(\mathrm{Na}_{2} \mathrm{CO}_{3} ;\right.$ a buffer $)$ and nitroblue tetrazolium (NBT; a substrate) were used and the inhibition in the rate of NBT reduction was read at $540 \mathrm{~nm}$. CAT (EC 1.11.1.6) activity assay was done as described in Aebi [44] method. Potassium phosphate (KH2PO4; a buffer) and hydrogen peroxide $\left(\mathrm{H}_{2} \mathrm{O}_{2}\right.$; a substrate) were used, and changes in the absorbance were read at $240 \mathrm{~nm}$. An APX (EC 1.11.1.11) activity assay was performed based on the method of Rao et al. [45] and the absorbance was read at $290 \mathrm{~nm}$. A GR (EC 1.6.4.1) activity assay was performed and the NADPH oxidation was monitored for three absorbance readings recorded at $340 \mathrm{~nm}$ [45].

Using the first fully expanding upper leaf on each plant, mRNA levels were assessed, and isolation of total RNA from leaf sample was performed using an RNeasy Mini Kit (Qiagen GmbH, Germany). Using RevertAid H Minus First Strand cDNA Synthesis Kit (Fermentas $\mathrm{GmbH}$, Germany), the subsequent synthesis of cDNA was performed. Primer sequences for semiquantitative and quantitative RT-PCR of the stress-related genes in Zea mays are presented in Table 4. The analysis for qRT-PCR was implemented on the iCycler Thermal Cycler (Bio-Rad, USA) using the instructions of IQ SYBR Green Supermix (Bio-Rad, USA) manufacture. As a reference gene for qPCR data normalization, the actin gene was used. Using LinRegPCR Software, the efficiency of the reactions was calculated [46]. Using the equation depicted in [47], signal values were derived from threshold cycles, with the average background subtracted. 
Table 4. Primers sequences for RT-qPCR of stress-related genes in Zea mays.

\begin{tabular}{|c|c|c|c|}
\hline The Gene & Reference Seq. & $5^{\prime}-3^{\prime}$ Primer Sequence & $\mathbf{T}_{\mathrm{A}}$ \\
\hline Actin & AB181991 & $\begin{array}{l}\text { F: CTCTGACAATTTCCCGCTCA, } \\
\text { R: ACACGCTTCCTCATGCTATCC }\end{array}$ & \multirow{6}{*}{$58^{\circ} \mathrm{C}$} \\
\hline$S O D$ & MG893090.1 & $\begin{array}{l}\text { F: TTCGCCATGCTGGTGATCTT, } \\
\text { R: CATGGACAACTACGGCCCTT }\end{array}$ & \\
\hline$C A T$ & GU984379 & $\begin{array}{l}\text { F: GGCTGCTTGAAGTTGTTCTCCT, } \\
\text { R: CTGCTAGTACCTCCTGATCCGTT }\end{array}$ & \\
\hline$A P X$ & KU747079.1 & $\begin{array}{l}\text { F: TGGCCTGCTCTTCCTCTAGT, } \\
\text { R: CATGCCACGCTAATCGAAGC }\end{array}$ & \\
\hline$G R$ & KX828561.1 & $\begin{array}{l}\text { F: CAACGCGCTTTGGTAACTCC, } \\
\text { R: GGGCCCTAATGAAGTGGAGG }\end{array}$ & \\
\hline $\operatorname{Prx} Q$ & AY789643 & $\begin{array}{l}\text { F: ACTTCACGCTCAAGGACCAG, } \\
\text { R: CCGCCTTCTTGTACTTCTCG }\end{array}$ & \\
\hline
\end{tabular}

\subsection{Analysis of the Resulting Data}

The data resulted from this study were analyzed by applying one-way analysis of variance [48]. For this purpose, the statistical software Statistix ${ }^{\circledR}$, version 8.1 (Copyright 2005, Analytical Software, USA) was applied. Treatment means were compared utilizing the LSD Test at $P \leq 0.05$.

\section{Results}

\subsection{The Desired Characteristics of Maize Grain Extract (MEg) Used in This Study}

Table 5 shows the main characteristics of MEg derived from maize grains. In addition to having high antioxidative activity $(89.22 \%)$, MEg is rich in antioxidants (e.g., proline, ascorbate, and glutathione) and phytohormones (IAA, GA $1, \mathrm{GA}_{3}$, cytokinins, including trans-zeatin, and salicylic acid (SA)), but it is poor in Sm compared to those in maize leaves. These essential ingredients make MEg a valuable biostimulator. Therefore, we used this valuable extract either alone or after enriching it with $\mathrm{Sm}$ to assess its defensive effects on Cd-stressed maize plants.

Table 5. Antioxidant and hormonal contents detected in maize grain extract (MEg) compared to their levels in maize leaves.

\begin{tabular}{cccc}
\hline Component & Unit & Value in MEg & Value in Maize Leaf \\
\hline & The antioxidative compounds: & $0.54 \pm 0.01$ \\
Free proline & & $24.66 \pm 0.39$ & $2.41 \pm 0.02$ \\
Ascorbic acid (AsA) & $\left(\mu \mathrm{mol} \mathrm{g}^{-1} \mathrm{FW}\right)$ & $14.26 \pm 0.07$ & $1.18 \pm 0.02$ \\
Glutathione (GSH) & & $8.85 \pm 0.03$ & $3.31 \pm 0.03$ \\
Silymarin (Sm) & $\left(\mu \mathrm{g} \mathrm{g}^{-1} \mathrm{DW}\right)$ & $0.02 \pm 0.00$ & Not determined \\
DPPH radical-scavenging activity & $\%$ & $89.22 \pm 1.62$ & $0.22 \pm 0.00$ \\
Indole-3-acetic acid (IAA) & Phytohormones: & $2.74 \pm 0.05$ & $0.04 \pm 0.02$ \\
Gibberellic acid 1(GA) & & $2.58 \pm 0.04$ & $0.05 \pm 0.03$ \\
Gibberellic acid 3 (GA $)$ & $2.75 \pm 0.06$ & Not determined \\
Total cytokinins (CKs) & & $3.96 \pm 0.08$ & $0.05 \pm 0.02$ \\
Trans-Zeatin ( $t$-Z) & & $2.55 \pm 0.04$ & Not determined \\
Salicylic acid (SA) & & $2.89 \pm 0.05$ & \\
\hline
\end{tabular}

Values presented in the table are means ( $n=3$ for all measures) \pm standard error.

3.2. The Response of Maize Plant Morphology and Leaf Photosynthetic Efficiency to MEg and/or Sm

In the absence of stress, plant height, leaves number, leaves area per plant, shoot fresh weight, shoot dry weight, and leaf photosynthetic efficiency (in terms of carboxylation efficiency (iCE), PSII efficiency (Fv / Fm), total chlorophyll and carotenoid contents, and pho- 
tochemical activity) were increased significantly with $2 \% \mathrm{MEg}$ or $0.5 \mathrm{mM} \mathrm{Sm}$. MEg enriched with Sm (MEg-Sm) was more efficient, increasing plant height by $24.3 \%$, leaves number by $27.4 \%$, leaves area by $28.3 \%$, shoot fresh weight by $33.6 \%$, shoot dry weight by $50.7 \%$, iCE by $130.1 \%$, Fv /Fm by $52.2 \%$, chlorophyll content by $82.2 \%$, carotenoid content by $108.3 \%$, and photochemical activity by $116.8 \%$ compared to the corresponding (normal) control (Figure 1).

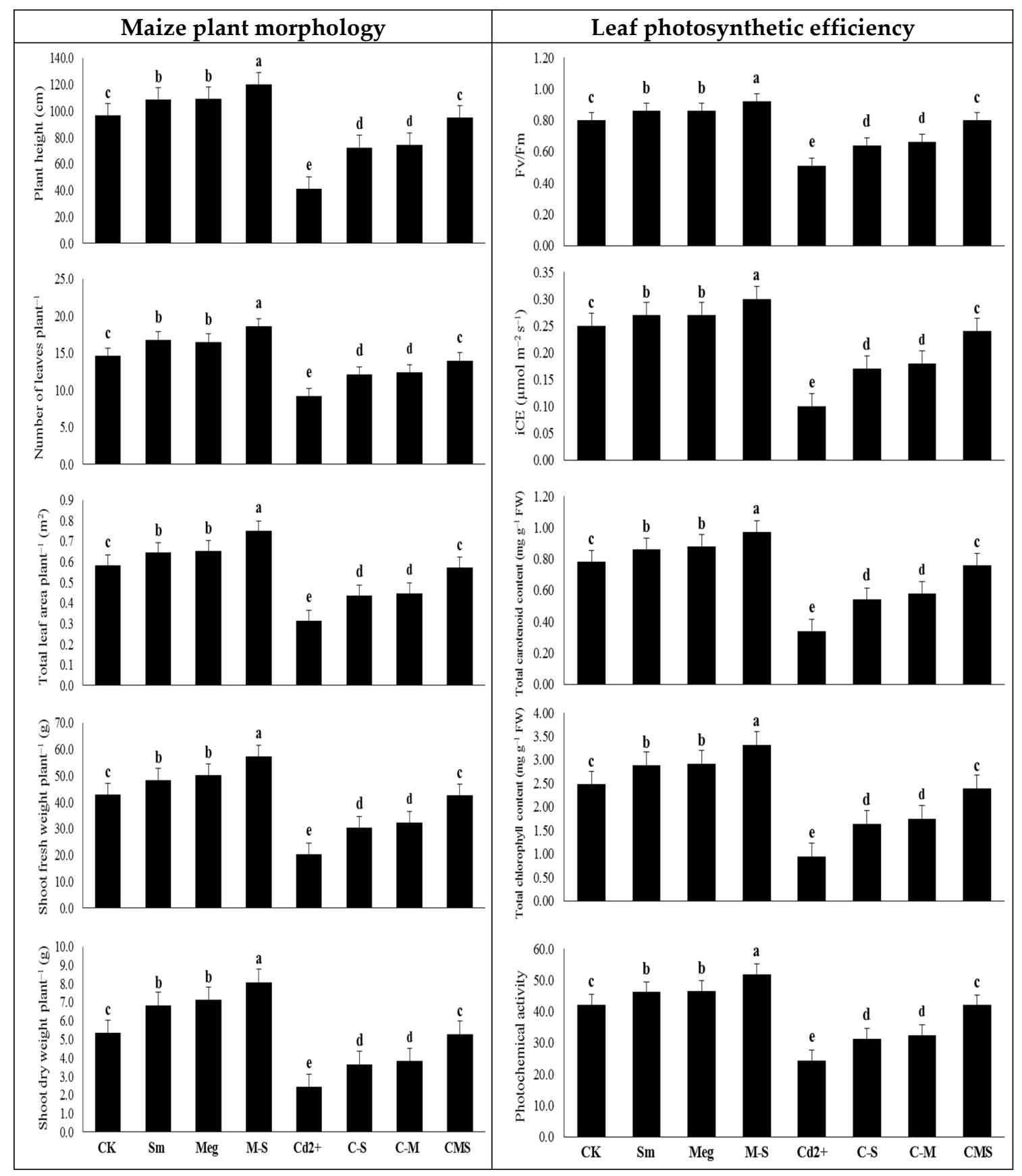

Figure 1. Response of maize plant morphology and leaf photosynthetic efficiency (carboxylation efficiency (iCE), PSII efficiency $\left(F_{v} / F_{m}\right)$, total chlorophyll and carotenoid contents, and photochemical activity) to foliar application of silymarin $(\mathrm{Sm})$, maize grain extract (MEg), or silymarin-enriched maize grain extract (MEg-Sm) under Cd stress. The same letters on the bars (mean $\pm \mathrm{SE}$ ) of the parameters indicate nonsignificant differences, whereas the significant differences are a result of different letters according to the least significant difference (LSD) test $(P \leq 0.05)$. CK $=$ control, $\mathrm{Sm}=$ silymarin, $\mathrm{Meg}=$ maize grain extract, $\mathrm{M}-\mathrm{S}=$ silymarin-enriched maize grain extract, $\mathrm{C}-\mathrm{S}=\mathrm{Cd}+\mathrm{Sm}, \mathrm{C}-\mathrm{M}=\mathrm{Cd}+\mathrm{Meg}$, $\mathrm{CMS}=\mathrm{Cd}+\mathrm{Meg}+\mathrm{Sm}$. 
Plant height, leaves number, leaves area per plant, shoot fresh weight, shoot dry weight, iCE, $F_{v} / F_{m}$, total chlorophyll content, total carotenoid content, and photochemical activity were markedly declined with $0.5 \mathrm{mM} \mathrm{Cd}$ applied in the irrigation solution. The decreases were $57.3 \%, 37.0 \%, 46.2 \%, 52.3 \%, 54.5 \%, 60.0 \%, 36.3 \%, 62.1 \%, 56.4 \%$, and $42.3 \%$, respectively, compared to the normal control (Figure 1).

Compared to the stressed control $(0.5 \mathrm{mM} \mathrm{Cd})$, all of the above parameters were significantly increased with MEg or Sm, whereas MEg-Sm was more efficient, as all ofthe above parameters increased by $130.1 \%, 52.2 \%, 82.2 \%, 108.3 \%, 116.8 \%, 140.0 \%, 56.9 \%$, $154.3 \%, 123.5 \%$, and $72.8 \%$, respectively. MEg-Sm treatment improved the morphological parameters and leaf photosynthesis efficiency of Cd-stressed plants to reach the same level as normal control plants (Figure 1).

\subsection{The Response of Oxidative Stress Markers and Their Damages to MEg and/or Sm}

In stress-free conditions, levels of $\mathrm{O}_{2}{ }^{\bullet-}, \mathrm{H}_{2} \mathrm{O}_{2}, \mathrm{MDA}$, and EL were slightly decreased, whereas $\mathrm{Cd}$ was not detected with $2 \% \mathrm{MEg}$, $0.5 \mathrm{mM} \mathrm{Sm}$, or even with MEg-Sm, which was more efficient, compared to the corresponding (normal) control (Figure 2).

The levels of $\mathrm{O}_{2}{ }^{\bullet-}, \mathrm{H}_{2} \mathrm{O}_{2}, \mathrm{MDA}$, EL, and Cd were considerably elevated with the addition of $0.5 \mathrm{mM} \mathrm{Cd}$ in the irrigation solution. The unwanted increases were $88.9 \%$, $219.9 \%, 110.1 \%, 233.2 \%$, and $52.6 \%$, respectively, compared to the normal control (Figure 2).

Compared to the stressed control $(0.5 \mathrm{mM} \mathrm{Cd})$, all of the above parameters were significantly decreased with MEg or Sm; however, MEg-Sm was more efficient, with all of the above parameters decreasing by $48.5 \%, 68.6 \%, 53.1 \%, 67.0 \%$, and $78.3 \%$, respectively. $\mathrm{Cd}$-stressed plants were able to minimize markers of oxidative stress, which was reflected in the considerable reduction of $\mathrm{El}$ and $\mathrm{Cd}^{2+}$ levels upon receiving $\mathrm{MEg}-\mathrm{Sm}$ as a foliar spray (Figure 2).
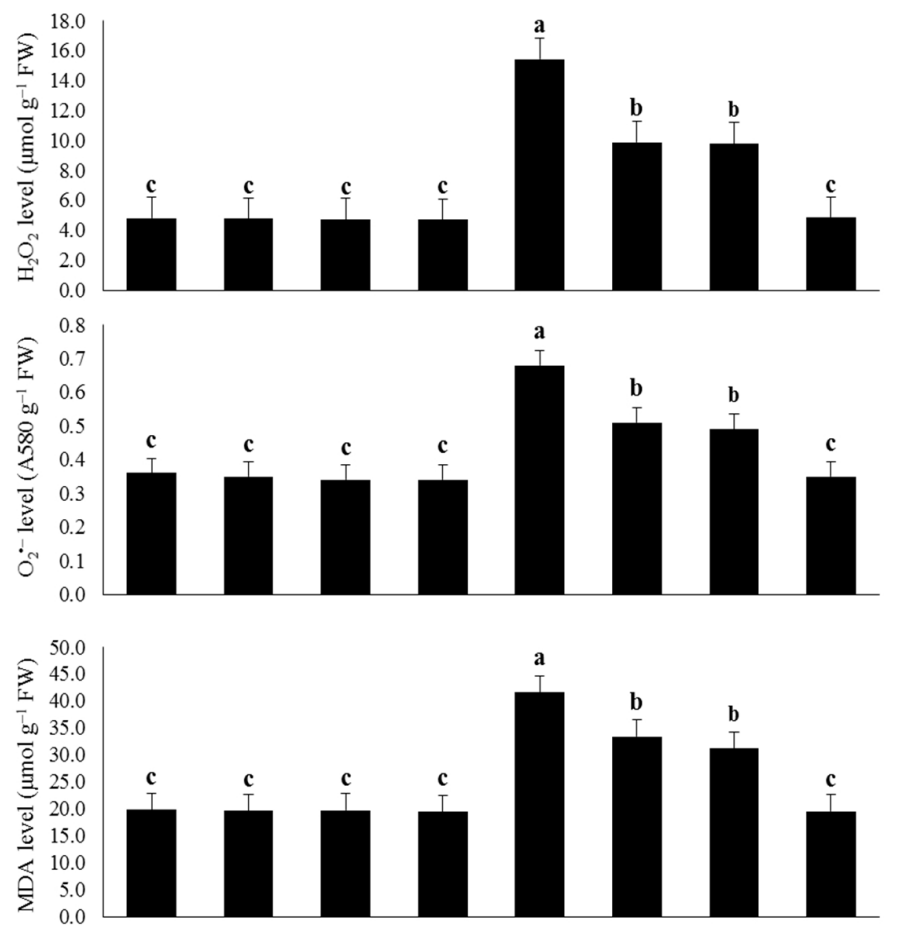

Figure 2. Cont. 


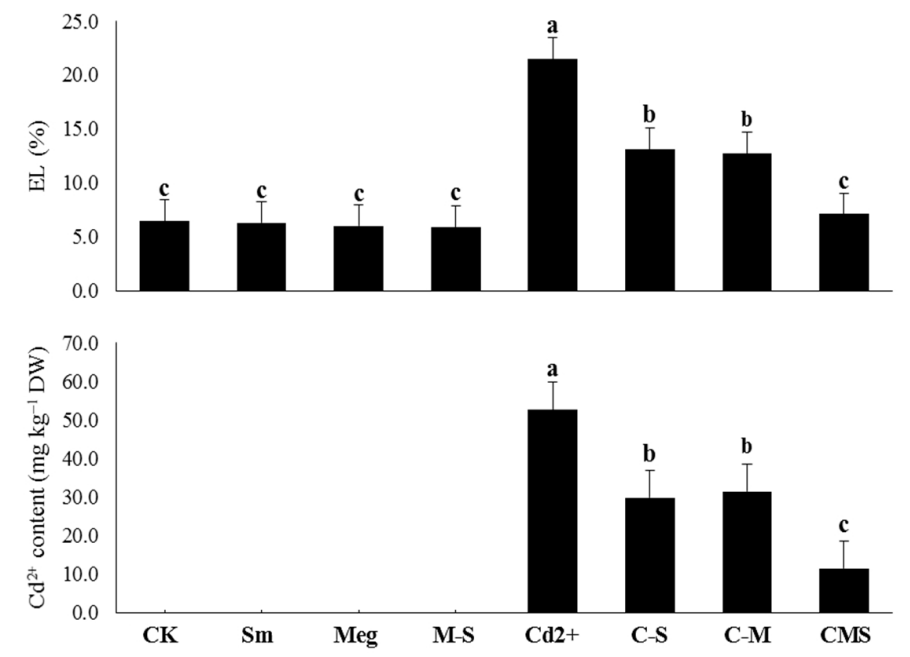

Figure 2. Response of oxidative stress markers (superoxide $\left(\mathrm{O} 2^{\bullet-}\right)$ and hydrogen peroxide $(\mathrm{H} 2 \mathrm{O} 2)$ levels) and their damage (lipid peroxidation as malondialdehyde (MDA) level and ionic leakage (EL, $\%)$ ) and $\mathrm{Cd}$ content of maize plants to foliar application of silymarin (Sm), maize grain extract (MEg), or silymarin-enriched maize grain extract (MEg-Sm) under Cd stress. The same letters on the bars (mean $\pm \mathrm{SE}$ ) of the parameters indicate nonsignificant differences, whereas the significant differences are a result of different letters according to the least significant difference (LSD) test $(P \leq 0.05)$. $(P \leq 0.05)$. $\mathrm{CK}=$ control, $\mathrm{Sm}=$ silymarin, $\mathrm{Meg}=$ maize grain extract, $\mathrm{M}-\mathrm{S}=$ silymarin-enriched maize grain extract, $\mathrm{C}-\mathrm{S}=\mathrm{Cd}+\mathrm{Sm}, \mathrm{C}-\mathrm{M}=\mathrm{Cd}+\mathrm{Meg}, \mathrm{CMS}=\mathrm{Cd}+\mathrm{Meg}+\mathrm{Sm}$.

3.4. The Response of Free Proline Content, Levels, and Redox States of Ascorbate (AsA) and Glutathione (GSH) to MEg and/or Sm

Under normal conditions, the contents of proline, AsA, GSH, and Sm were increased as the redox state of AsA and GSH increased by $2 \%$ MEg or $0.5 \mathrm{mM} \mathrm{Sm}$; the increase in Sm content was significant with Sm treatment, whereas the increase in proline, AsA, and GSH content was significant with MEg treatment. MEg-Sm was more efficient; it significantly increased proline content by $69.0 \%$, AsA content by $100.8 \%$, AsA redox state by $1.7 \%$, GSH content by $96.6 \%$, GSH redox state by $1.9 \%$, and Sm content by $52.7 \%$ compared to the corresponding (normal) control (Figure 3).

Proline, AsA, GSH, and Sm levels, as well as the redox state of AsA and GSH, were significantly elevated under Cd stress. The increases were $130.6 \%, 167.2 \%, 172.9 \%, 84.8 \%$, $40.5 \%$, and $43.7 \%$, respectively, compared to the normal control (Figure 3 ).

Compared to the stressed control $(0.5 \mathrm{mM} \mathrm{Cd})$, all of the above parameters were further increased with MEg or Sm. However, MEg-Sm was more efficient, with all of the above parameters increasing by $113.7 \%, 54.3 \%, 83.9 \%, 59.0 \%, 24.8 \%$, and $55.6 \%$, respectively. The Cd-stressed maize plants were able to amass more antioxidants such as Proline, AsA, GSH, and Sm to efficiently cope with markers of oxidative stress upon receiving MEg-Sm as a foliar spray (Figure 3). 

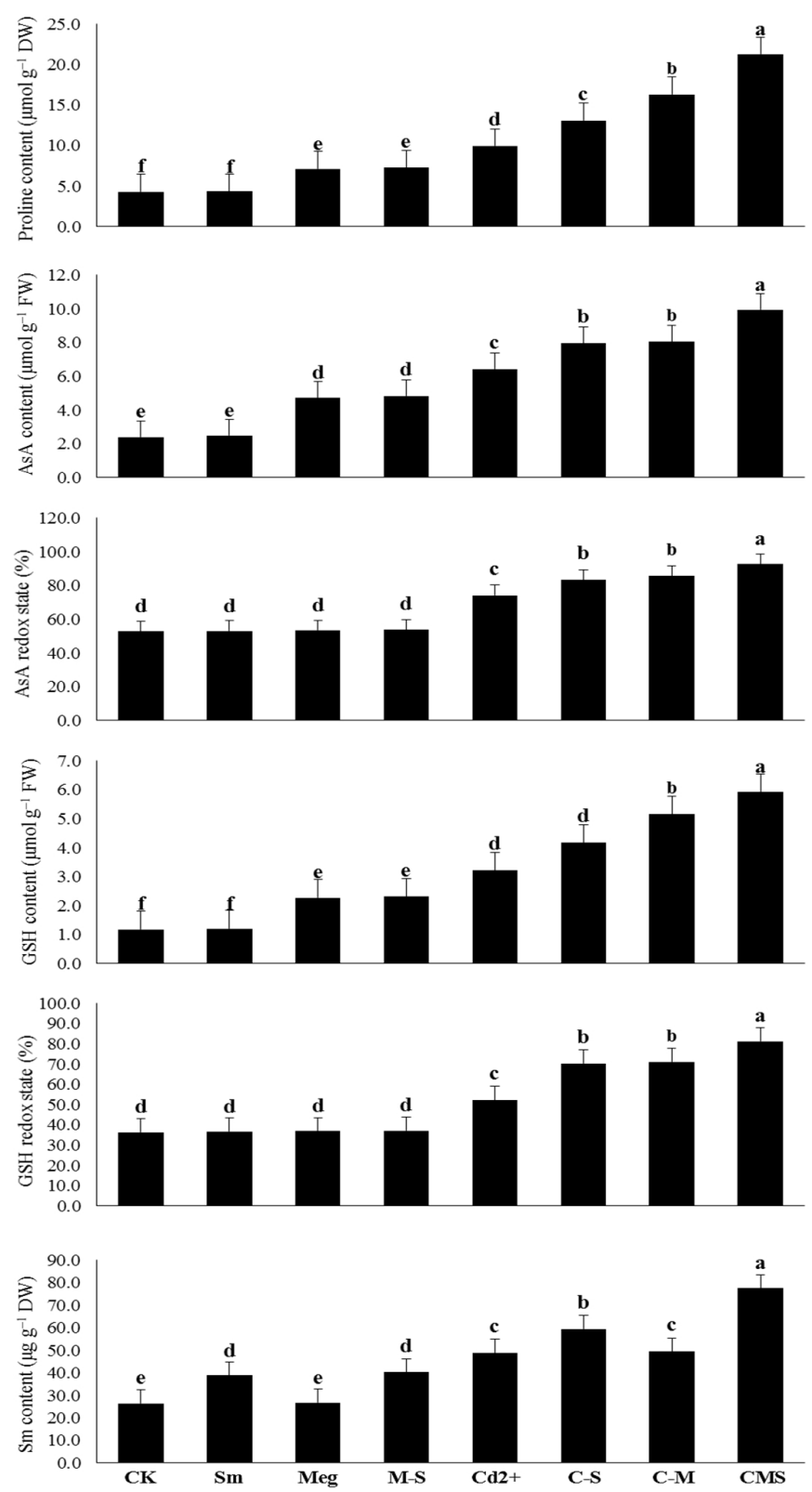

Figure 3. Response of free proline content, level, and redox state of ascorbate (AsA) and glutathione (GSH) of maize plants to foliar application of silymarin (Sm), maize grain extract (MEg), or silymarin-enriched maize grain extract (MEg-Sm) under Cd stress. The same letters on the bars (mean $\pm \mathrm{SE}$ ) of the parameters indicate nonsignificant differences, while the significant differences are a result of different letters according to the least significant difference (LSD) test $(P \leq 0.05)$. $\mathrm{CK}=$ control, $\mathrm{Sm}$ = silymarin, $\mathrm{Meg}=$ maize grain extract, $\mathrm{M}-\mathrm{S}=$ silymarin-enriched maize grain extract, $C-S=C d+S m, C-M=C d+M e g, C M S=C d+M e g+S m$.

\subsection{The Response of Enzyme Activities and Hormonal Levels to MEg and/or Sm}

In the nonstress conditions, SOD, CAT, APX, and GR activities were slightly elevated with MEg, Sm, or even MEg-Sm. However, levels of IAA, GA $1, \mathrm{GA}_{3}$, and trans-zeatin were slightly increased with $\mathrm{Sm}$ but significantly increased with MEg or MEg-Sm, with a nonsignificant preference for MEg-Sm treatment, which increased SOD, CAT, APX, and GR activities by $3.8 \%, 4.5 \%, 6.7 \%$, and $5.9 \%$, respectively, and IAA, $\mathrm{GA}_{1}, \mathrm{GA}_{3}$, and trans-zeatin levels by $25.0 \%, 20.5 \%, 16.2 \%$, and $67.8 \%$, respectively, as compared to the corresponding (normal) control (Figure 4). 


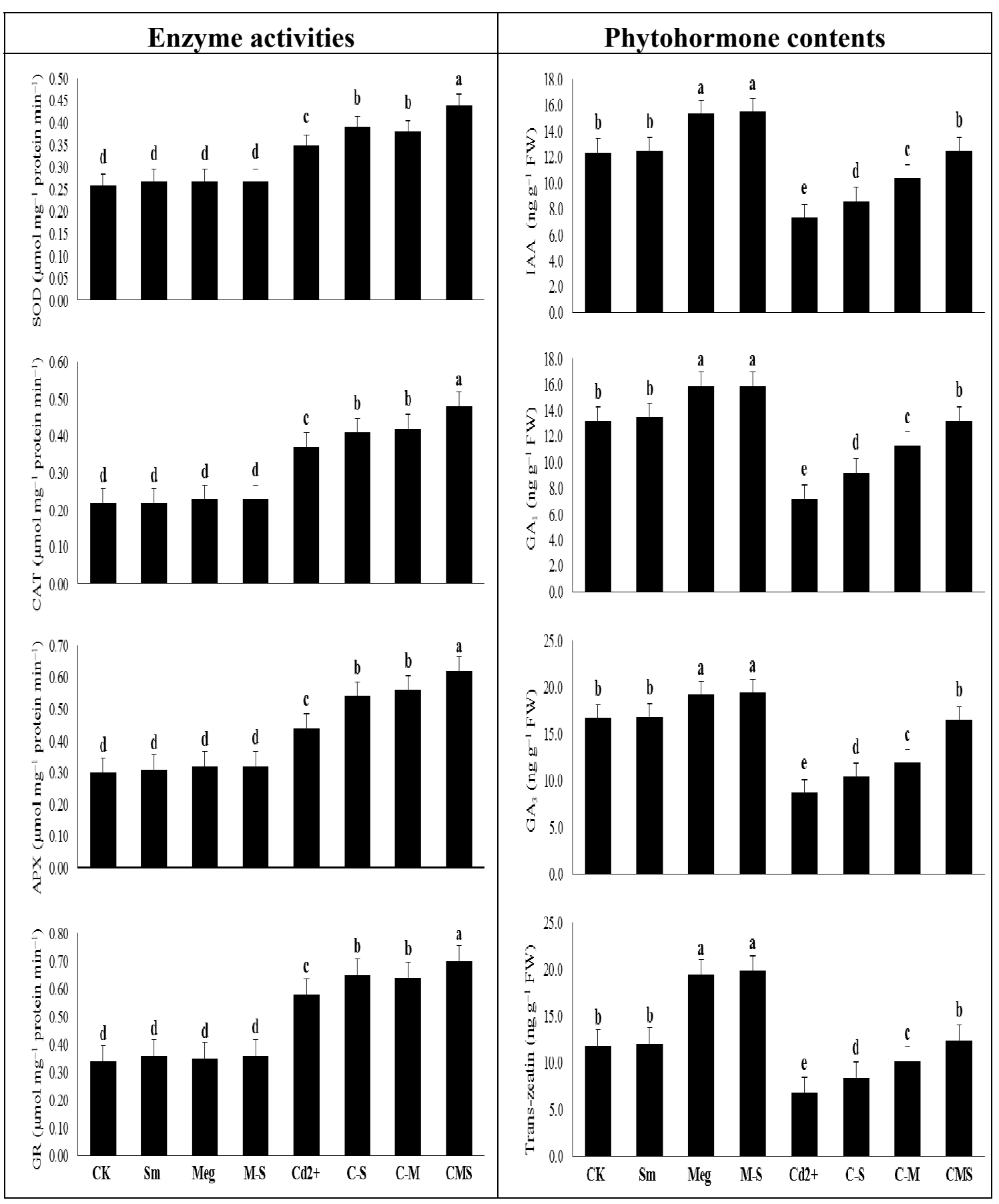

Figure 4. Response of enzyme (superoxide dismutase (SOD), catalase (CAT), ascorbate peroxidase (APX), and glutathione reductase (GR)) activities, as well as leaf phytohormone levels (indole-3-acetic acid (IAA), gibberellic acids 1 and 3 (GA1 and GA3), and cytokinin (trans-zeatin)) of maize plants to foliar application of silymarin (Sm), maize grain extract (MEg), or silymarin-enriched maize grain extract (MEg-Sm) under Cd stress. The same letters on the bars (mean \pm SE) of the parameters indicate nonsignificant differences, whereas the significant differences are a result of different letters according to the least significant difference (LSD) test $(P \leq 0.05) . \mathrm{CK}=$ control, $\mathrm{Sm}=$ silymarin, $\mathrm{Meg}=$ maize grain extract, $\mathrm{M}-\mathrm{S}=$ silymarin-enriched maize grain extract, $\mathrm{C}-\mathrm{S}=\mathrm{Cd}+\mathrm{Sm}, \mathrm{C}-\mathrm{M}=\mathrm{Cd}+\mathrm{Meg}, \mathrm{CMS}=\mathrm{Cd}+\mathrm{Meg}+\mathrm{Sm}$.

Under Cd stress conditions, SOD, CAT, APX, and GR activities were markedly elevated by $34.6 \%, 68.2 \%, 46.7 \%$, and $70.6 \%$ respectively, whereas the levels of IAA, GA 1 , $\mathrm{GA}_{3}$, and trans-zeatin were significantly decreased by $41.1 \%, 45.5 \%, 47.9 \%$, and $42.4 \%$, respectively, compared to the normal control (Figure 4). 
Compared with the Cd-stressed control, SOD, CAT, APX, and GR activities were significantly increased along with increased levels of IAA, GA $1, \mathrm{GA}_{3}$, and trans-zeatin with MEg or Sm. However, MEg-Sm was more efficient, with all of the above parameters increasing by $25.7 \%, 29.7 \%, 40.9 \%$, and $20.7 \%$ for enzyme activities and by $71.2 \%, 83.3 \%$, $89.7 \%$, and $82.4 \%$ for hormonal levels, respectively. Cd-stressed maize plants were able to increase their enzymatic activities along with various antioxidants to cope with markers of oxidative stress and stabilize their hormonal contents upon receiving MEg-Sm as a foliar spray (Figure 4).

\subsection{The Response of Gene Transcript Levels to MEg and/or Sm}

Using quantitative and conventional RT-PCR, genetic relative expression of enzymatic antioxidants (SOD, CAT, APX, GR, and PrxQ) were signalized for normal and Cd-stressed maize plants and stressed plants treated with MEg, Sm, or MEg-Sm (Figure 5).

Under normal conditions, transcriptional levels of SOD, CAT, APX, GR, and PrxQ genes were slightly or not affected by MEg, Sm, or even MEg-Sm. The recorded increases of gene expression levels were $8.3 \%, 0 \%, 16.7 \%, 16.7 \%$, and $0 \%$, respectively, upon treatment by MEg-Sm compared to the corresponding (normal) control (Figure 5).

Transcriptional levels of SOD, CAT, APX, GR, and PrxQ genes were markedly increased under $0.5 \mathrm{mM} \mathrm{Cd}$, and the increases were $191.7 \%$, 250.0\%, 350.0\%, 391.7\%, and 441.7\%, respectively, compared to the normal control (Figure 5).

Compared to the Cd-stressed control, the transcript levels of the SOD, CAT, APX, GR, and PrxQ genes were significantly increased with MEg or Sm, whereas MEg-Sm was more efficient, and increased the aforementioned gene transcriptional levels by $94.3 \%, 81.0 \%$, $55.6 \%, 55.9 \%$, and $50.8 \%$, respectively. Cd-stressed maize plants were able to transcribe more gene-encoding enzymatic antioxidants along with various nonenzymatic antioxidants to cope with markers of oxidative stress upon receiving MEg-Sm as a foliar spray (Figure 5).

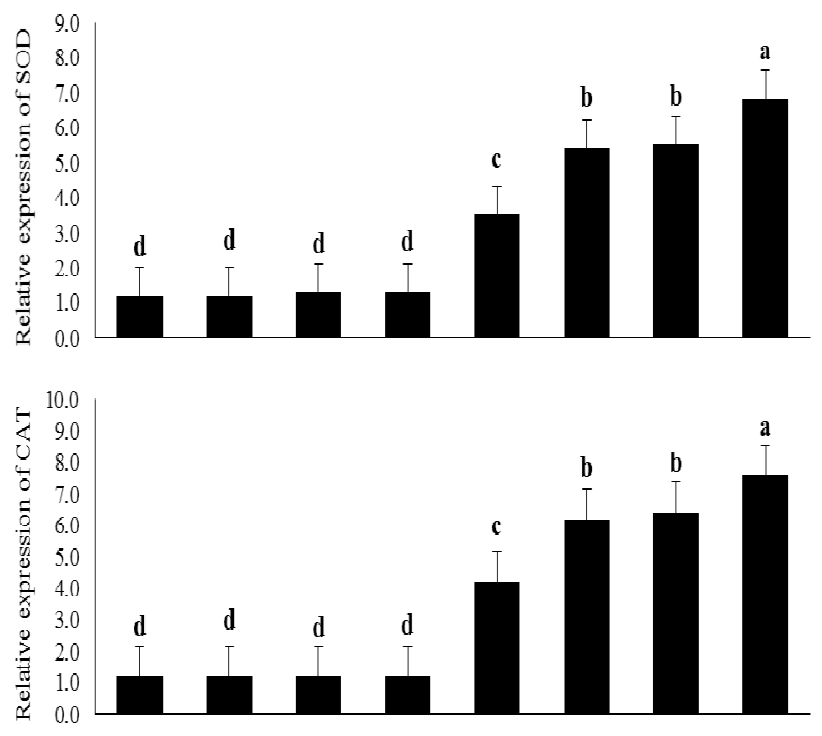

Figure 5. Cont. 

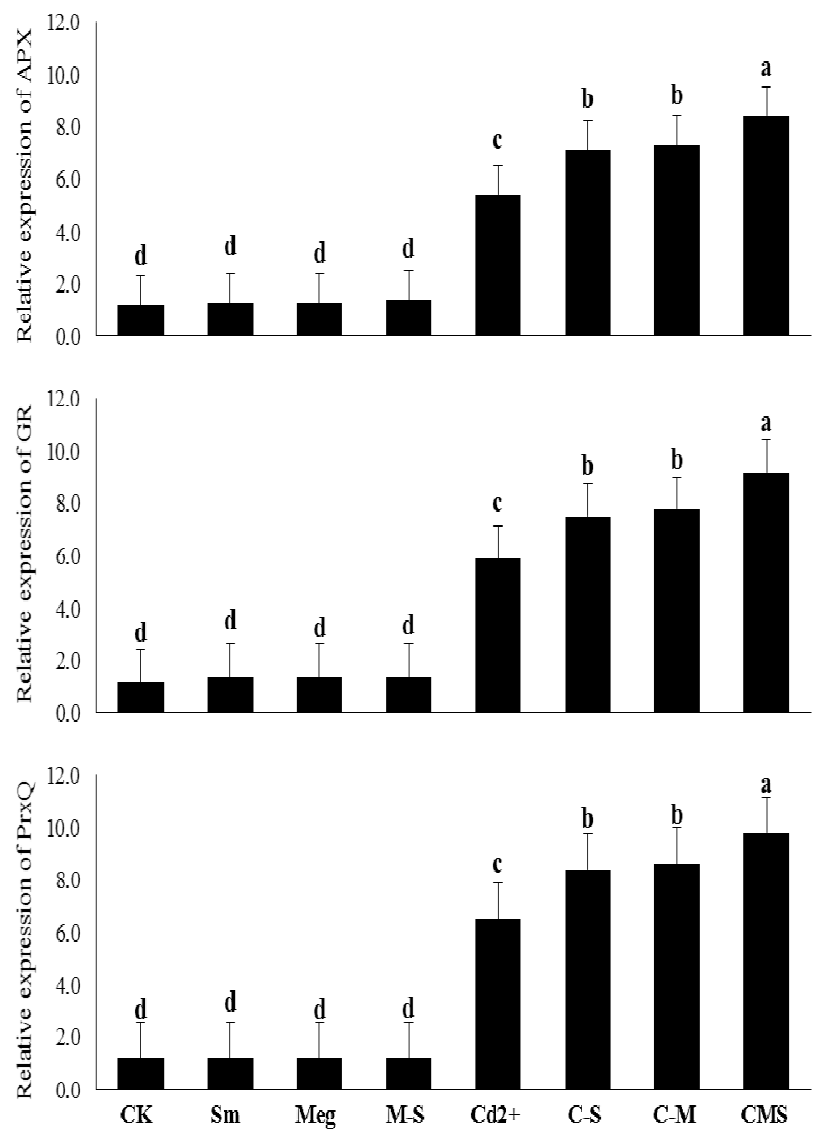

Figure 5. Response of antioxidant enzyme-encoding gene transcript levels (transcriptional levels were quantified by qPCR relative to actin transcriptional level, qPCR data represent the average from three independent experiments with two technical replicates each) of maize plants to foliar application of silymarin (Sm), maize grain extract (MEg), or silymarin-enriched maize grain extract (MEg-Sm) under $\mathrm{Cd}$ stress. The same letters on the bars (mean $\pm \mathrm{SE}$ ) of the parameters indicate nonsignificant differences, whereas the significant differences are a result of different letters according to the least significant difference (LSD) test $(P \leq 0.05)$. $\mathrm{CK}=$ control, $\mathrm{Sm}=$ silymarin, $\mathrm{Meg}=$ maize grain extract, $\mathrm{M}-\mathrm{S}=$ silymarin-enriched maize grain extract, $\mathrm{C}-\mathrm{S}=\mathrm{Cd}+\mathrm{Sm}, \mathrm{C}-\mathrm{M}=\mathrm{Cd}+\mathrm{Meg}, \mathrm{CMS}=\mathrm{Cd}+\mathrm{Meg}+\mathrm{Sm}$.

\subsection{The Interrelationship among the Traits Evaluated in Response to MEg and/or Sm}

Key components were computed to verify the association among the attributes evaluated. The first two primary components displayed the most variability by approximately $96.8 \%$ ( $74.9 \%$ by PC 1 and $21.9 \%$ by PC2). Next, PC1 and PC 2 were utilized to construct the PC-biplot (Figure 6). Parallel or close vectors represented features, indicating a strong positive association, whereas vectors with angles close to $180^{\circ}$ indicated a negative association. The traits evaluated in the current study can be divided into three sets. The first set consisted of Pro, AsA, GSH, AsA redox state, GSH redox state, Sm, SOD, CAT, APX, GR, RE SOD, RE CAT, RE APX, RE GR, and RE PrxQ. The second set included PH, LN, LA, FW, DW, iCE, Fv/Fm, TCh, TCa, PhA, IAA, GA, $\mathrm{GA}_{3}$, and T-Z. The third set contained $\mathrm{Cd}^{2+}$, MDA, EL, $\mathrm{O}_{2}{ }^{\bullet-}$, and $\mathrm{H}_{2} \mathrm{O}_{2}$. The traits within each group displayed a high association with each other, whereas an intermediate positive association was detected among traits of the first and third groups. The first group exhibited a negative association with the second group. 


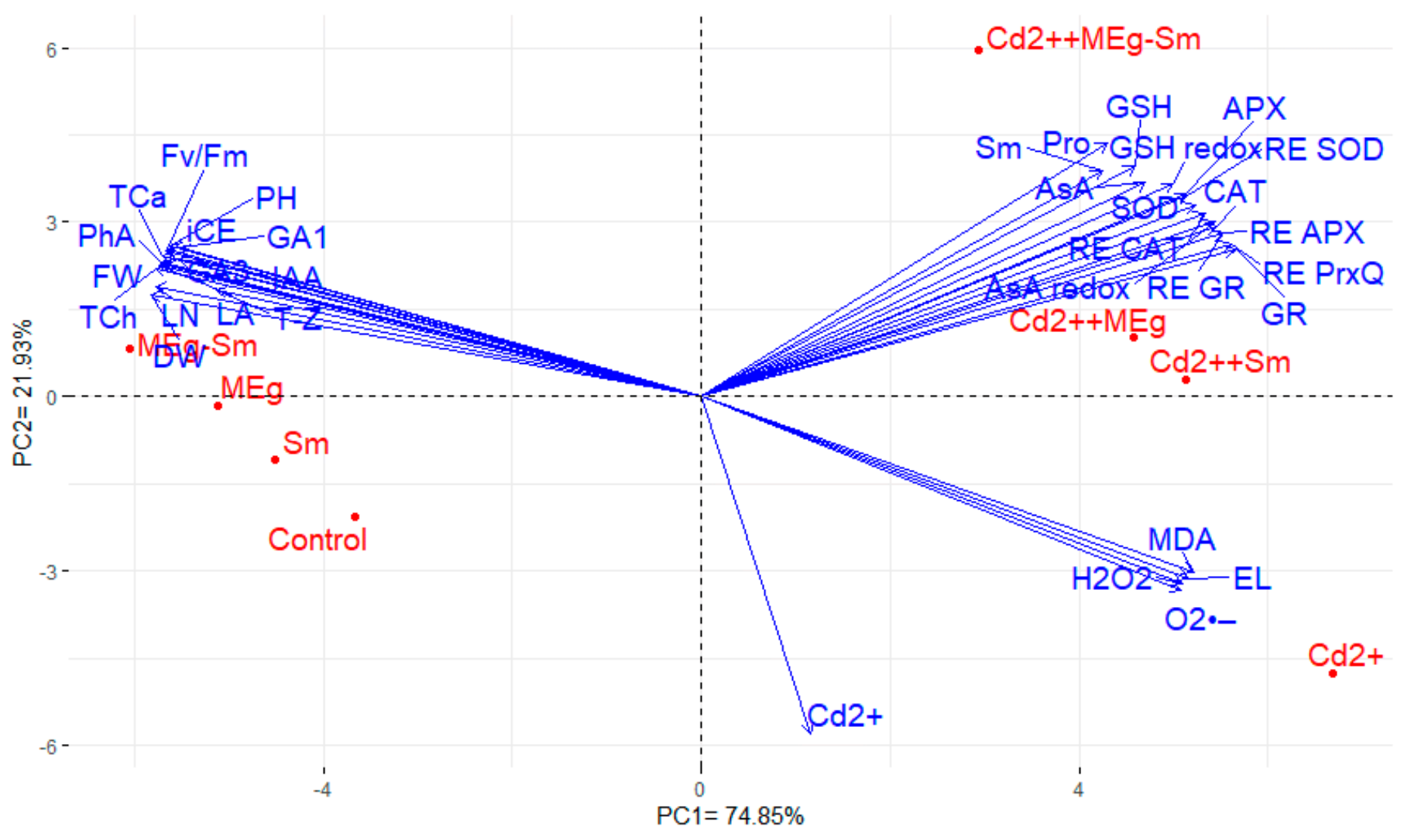

Figure 6. Biplot of analysis of prime components demonstrating the relationship among the traits assessed. Plant height (PH), number of leaves (LN), total leaf area (LA), shoot fresh weight (FW), shoot dry weight (DW), instantaneous carboxylation efficiency (iCE), photosystem II efficiency (Fv/Fm), total chlorophyll (TCh), carotenoid contents ((TCa), photochemical activity (PhA), superoxide $\left(\mathrm{O}^{\bullet-}\right)$, hydrogen peroxide (H2O2), lipid peroxidation as malondialdehyde (MDA), ionic leakage (EL), cadmium (Cd2+), proline (Pro), ascorbate (AsA), glutathione (GSH), ascorbate redox state (AsA redox), glutathione redox state (GSH redox), silymarin ( $\mathrm{Sm}$ ), superoxide dismutase (SOD), catalase (CAT), ascorbate peroxidase (APX), glutathione reductase (GR), relative expression of SOD (RE SOD), relative expression of CAT (RE CAT), relative expression of APX (RE APX), relative expression of GR (RE GR), relative expression of PrxQ (RE PrxQ), indole-3-acetic acid (IAA), gibberellic acids 1 and 3 (GA1 and GA3), and cytokinin trans-zeatin (T-Z).

\section{Discussion}

No information is available on the foliar application of maize plants with a maize grain extract (MEg) enriched with silymarin (Sm); MEg-Sm to attenuate the adverse impacts of cadmium (Cd) stress on plant performance, which responded positively to the novel MEg-Sm. Recently, some articles have been reported positive changes in plant growth, biochemical attributes, and plant defensive system (e.g., antioxidative enzymes and nonenzymatic antioxidants) after treating plants with MEg alone under some stresses [3,20-23], indicating the importance of MEg. However, the current study provides impressive results such as a considerable increase in maize plant performance and defense system along with gene expression related to antioxidant enzymes due to the application of MEg-Sm, which outperformed MEg alone due to that $\mathrm{Sm}$ increased the efficiency of the extract.

Presently, sustainable maize returns challenge various issues such as reduced soil fertility and increased degradation due to contamination of farmland with heavy metals, including $\mathrm{Cd}$. Cd stress is one of the key concerns facing maize production, restricting crop yield. $\mathrm{Cd}$ frequently causes disturbances of various morphophysiobiochemical and molecular features. It restricts plant growth, disrupts chlorophyll biosynthesis, and thus photosynthesis, and negatively affects the defense system and antioxidant gene expression 
in plants $[8,14]$. Therefore, attenuating the toxic effect of $\mathrm{Cd}$ on plant growth and biochemical processes remains a constant concern of scientists. There is an urgent need to ameliorate $\mathrm{Cd}$ tolerance in maize through sustainable and ecofriendly strategies, which are the key to achieving security for more foods for an ever-expanding population. In the present study, $0.5 \mathrm{mM} \mathrm{Cd}$ severely decreased maize plant growth traits (e.g., plant height, leaves number, leaves area per plant, fresh and dry weight of shoot system), photosynthetic efficiency (instantaneous carboxylation efficiency; iCE, pigment contents, $F_{v} / F_{m}$, and photochemical activity) and hormonal contents (Figures 1 and 4, Table 6). These negative results coincided with a harmful increase in markers of oxidative stress levels $\left(\mathrm{O}_{2}{ }^{--}\right.$and $\left.\mathrm{H}_{2} \mathrm{O}_{2}\right)$, lipid peroxidation (MDA), ionic leakage (EL), and accumulation of $\mathrm{Cd}$ (Figure 2). All of these negative results encouraged an increase in the plant's enzymatic and nonenzymatic antioxidative defense system and Sm content (Figures 3 and 4, Table 6), and transcriptional level of genes related to enzymatic antioxidants (Figure 5, Table 6) to enable plants to cope with markers of oxidative stress overproduced by Cd stress.

The number of green leaves obtained from the tallest plants should be optimized; thus, green leaf area is a pivotal strategy for increasing photosynthesis efficiency and increasing dry matter output. Under normal or Cd stress conditions, foliar treating maize plants with MEg or Sm led to a significant rise in plant height, leaves number, and leaves area, which reflected positively on plant weight, especially dry matter output (Figure 1, Table 6). Treatment with Sm-enriched MEg (MEg-Sm) outperformed either MEg or Sm alone. This may be due to the improving effect of Sm, which has added to the various benefits of MEg. In addition to having a high antioxidative activity (89.22\%), MEg contains several stimulating mechanisms such as antioxidants (proline, ascorbate; AsA, and glutathione; GSH) and various phytohormones (IAA, $\mathrm{GA}_{1}, \mathrm{GA}_{3}$, cytokinins including transzeatin, and salicylic acid; SA) (Table 5). The increase in plant height and number of leaves resulting from the application of $\mathrm{MEg}$-Sm contributed to an increase in plant leaf area, accompanied by an increase in photosynthetic pigment contents, all of which contributed to an increase in photosynthetic efficiency $\left(F_{v} / F_{m}\right.$ and photochemical activity). These positive results were positively reflected in dry matter accumulation (Figure 1, Table 6). All these positive results were achieved by MEg-Sm due to the minimized levels of $\mathrm{Cd}$ and markers of oxidative stress, which contributed to the reduction of MDA and EL (Figure 2, Table 6).

The enhanced effect of MEg-Sm (which outperformed the enhanced effect of MEg or Sm) on transcriptional gene levels related to antioxidant enzymes (SOD, CAT, APX, $\mathrm{CR}$, and PrxQ) efficiently contributed to increasing levels and activities of antioxidant enzymes (Figures 4 and 5, Table 6), which in turn contributed to the improvement of hormonal homeostasis (Figure 4, Table 6). The significant improvement in the antioxidant defense state of maize plants by MEg-Sm treatment contributed to the minimization of $\mathrm{Cd}^{2+}$ ions (Figure 2, Table 6), which resulted in the plants recovering from stress due to ROS suppression. This may enable plants to stabilize and balance their hormones so that they perform well.

It has been shown that antioxidants and hormonal homeostasis regulate plant growth and their physiobiochemical performance under Cd stress $[6,23,49]$. As shown in Table 5, MEg is rich in antioxidants and phytohormones, which are important mechanisms for improving growth, dry matter production, and physiobiochemical attributes, as well as the antioxidant defense system of maize plants grown under Cd stress (Figures 1-5, Table 6). As a crucial mechanism that helped maize plants withstand $\mathrm{Cd}$ stress, increases in AsA and GSH contents and redox states were noticed (Figure 3, Table 6). An increase in hormonal content and homeostasis was also observed as another effective mechanism that enabled plants to withstand the effects of Cd stress (Figure 4, Table 6). 
Table 6. Changes (\%) in morphophysiobiochemistry attributes, and relative expression of antioxidant enzyme genes relative to the control in Cd-stressed maize plants treated with maize grain extract enriched with silymarin. Three color scale heatmap, yellow as the midpoint of control and parameters with insignificant values compared to control, red for changes below control values, and green for changes over control values.

\begin{tabular}{|c|c|c|c|c|c|c|c|c|}
\hline \multirow[b]{2}{*}{ Parameter } & \multicolumn{8}{|c|}{ Treatments } \\
\hline & Control & Sm & MEg & MEg-Sm & $\mathrm{Cd}^{2+}$ & $\mathrm{Cd}^{2+}+\mathrm{Sm}$ & $\mathrm{Cd}^{2+}+\mathrm{MEg}$ & $\mathrm{Cd}^{2+}+\mathrm{MEg}-\mathrm{Sm}$ \\
\hline Plant height & $96.4 \mathrm{c}$ & $+12.8 \mathrm{~b}$ & $+13.3 \mathrm{~b}$ & $+24.3 \mathrm{a}$ & $-57.3 \mathrm{e}$ & $-24.9 \mathrm{~d}$ & $-22.7 \mathrm{~d}$ & $-1.7 \mathrm{c}$ \\
\hline Leaf number & $14.6 \mathrm{c}$ & $+15.1 \mathrm{~b}$ & $+13.0 \mathrm{~b}$ & $+27.4 \mathrm{a}$ & $-37.0 \mathrm{e}$ & $-17.1 \mathrm{~d}$ & $-15.1 \mathrm{~d}$ & $-4.1 c$ \\
\hline Leaf area & $0.584 \mathrm{c}$ & $+10.3 \mathrm{~b}$ & $+11.6 \mathrm{~b}$ & $+28.3 \mathrm{a}$ & $-46.2 \mathrm{e}$ & $-25.3 d$ & $-23.3 \mathrm{~d}$ & $-2.1 \mathrm{c}$ \\
\hline Shoot FW & $42.8 \mathrm{c}$ & $+13.1 \mathrm{~b}$ & $+17.1 \mathrm{~b}$ & $+33.6 \mathrm{a}$ & $-52.3 \mathrm{e}$ & $-29.0 \mathrm{~d}$ & $-24.8 \mathrm{~d}$ & $-0.7 \mathrm{c}$ \\
\hline Shoot DW & $5.36 \mathrm{c}$ & $+27.6 \mathrm{~b}$ & $+32.8 \mathrm{~b}$ & $+50.7 \mathrm{a}$ & $-54.5 \mathrm{e}$ & $-31.7 \mathrm{~d}$ & $-28.7 \mathrm{~d}$ & $-1.3 \mathrm{c}$ \\
\hline iCE & $0.25 c$ & $+8.0 \mathrm{~b}$ & $+8.0 \mathrm{~b}$ & $+20.0 \mathrm{a}$ & $-60.0 \mathrm{e}$ & $-32.0 \mathrm{~d}$ & $-28.0 \mathrm{~d}$ & $-4.0 c$ \\
\hline$F_{v} / F_{m}$ & $0.80 \mathrm{c}$ & $+7.5 \mathrm{~b}$ & $+7.5 \mathrm{~b}$ & $+15.0 \mathrm{a}$ & $-36.3 \mathrm{e}$ & $-20.0 \mathrm{~d}$ & $-17.5 \mathrm{~d}$ & $0 \mathrm{c}$ \\
\hline Chl. content & $2.48 \mathrm{c}$ & $+16.5 \mathrm{~b}$ & $+17.7 \mathrm{~b}$ & $+33.9 \mathrm{a}$ & $-62.1 \mathrm{e}$ & $-33.9 \mathrm{~d}$ & $-29.4 \mathrm{~d}$ & $-3.6 c$ \\
\hline Carot. content & $0.78 \mathrm{c}$ & $+10.3 \mathrm{~b}$ & $+12.8 \mathrm{~b}$ & $+24.4 \mathrm{a}$ & $-56.4 \mathrm{e}$ & $-30.8 d$ & $-25.6 \mathrm{~d}$ & $-2.6 c$ \\
\hline Ph.ch. activity & $42.1 \mathrm{c}$ & +9.7b & $+10.5 \mathrm{~b}$ & $+23.0 \mathrm{a}$ & $-42.3 \mathrm{e}$ & $-25.9 \mathrm{~d}$ & $-23.0 \mathrm{~d}$ & $-0.2 c$ \\
\hline $\mathrm{O}_{2}^{\bullet-}$ level & $0.36 c$ & $-2.8 c$ & $-5.6 c$ & $-5.6 c$ & $+88.9 \mathrm{a}$ & $+41.7 \mathrm{~b}$ & $+36.1 \mathrm{~b}$ & $-2.8 c$ \\
\hline $\mathrm{H}_{2} \mathrm{O}_{2}$ level & $4.82 \mathrm{c}$ & $-1.0 \mathrm{c}$ & $-2.3 c$ & $-2.7 c$ & $+220 \mathrm{a}$ & $+105 \mathrm{~b}$ & $+103 \mathrm{~b}$ & $+0.4 \mathrm{c}$ \\
\hline MDA level & $19.8 \mathrm{c}$ & $-1.0 \mathrm{c}$ & $-0.5 c$ & $-2.0 c$ & $+110 \mathrm{a}$ & $+68.7 b$ & $+57.6 \mathrm{~b}$ & $-1.5 c$ \\
\hline EL\% & $6.44 \mathrm{c}$ & $-2.0 c$ & $-7.1 c$ & $-8.7 c$ & $+233 a$ & $+103 \mathrm{~b}$ & $+97.2 \mathrm{~b}$ & $+10.1 \mathrm{c}$ \\
\hline Pro content & $4.32 \mathrm{f}$ & $+0.9 \mathrm{f}$ & $+65.3 \mathrm{e}$ & $+69.0 \mathrm{e}$ & $+131 \mathrm{~d}$ & $+204 c$ & $+278 \mathrm{~b}$ & $+393 \mathrm{a}$ \\
\hline AsA content & $2.41 \mathrm{e}$ & $+3.7 \mathrm{e}$ & $+95.9 \mathrm{~d}$ & $+101 \mathrm{~d}$ & $+167 \mathrm{c}$ & $+230 \mathrm{~b}$ & $+234 \mathrm{~b}$ & $+312 \mathrm{a}$ \\
\hline AsA redox st. & $52.8 \mathrm{~d}$ & $+0.6 \mathrm{~d}$ & $+1.1 \mathrm{~d}$ & $+1.7 \mathrm{~d}$ & $+40.5 \mathrm{c}$ & $+57.8 \mathrm{~b}$ & $+62.3 \mathrm{~b}$ & $+75.4 \mathrm{a}$ \\
\hline GSH content & $1.18 \mathrm{f}$ & $+2.5 \mathrm{f}$ & $+93.2 \mathrm{e}$ & $+96.6 \mathrm{e}$ & $+173 d$ & $+254 \mathrm{c}$ & $+337 b$ & $+402 \mathrm{a}$ \\
\hline GSH redox st. & $36.4 \mathrm{~d}$ & $+1.1 \mathrm{~d}$ & $+1.4 \mathrm{~d}$ & $+1.9 \mathrm{~d}$ & $+43.7 \mathrm{c}$ & $+93.4 \mathrm{~b}$ & $+95.6 \mathrm{~b}$ & $+124 \mathrm{a}$ \\
\hline Sm content & $26.4 \mathrm{e}$ & $+47.3 \mathrm{~d}$ & $+1.5 \mathrm{e}$ & $+52.7 \mathrm{~d}$ & $+84.8 \mathrm{c}$ & $+125 \mathrm{~b}$ & $+87.1 \mathrm{c}$ & $+194 \mathrm{a}$ \\
\hline SOD activity & $0.26 \mathrm{~d}$ & $+3.8 \mathrm{~d}$ & $+3.8 \mathrm{~d}$ & $+3.8 \mathrm{~d}$ & $+34.6 \mathrm{c}$ & $+50.0 \mathrm{~b}$ & $+46.2 \mathrm{~b}$ & $+69.2 \mathrm{a}$ \\
\hline CAT activity & $0.22 \mathrm{~d}$ & $0 \mathrm{~d}$ & $+4.5 \mathrm{~d}$ & $+4.5 \mathrm{~d}$ & $+68.2 c$ & $+86.4 \mathrm{~b}$ & $+90.9 b$ & $+118 \mathrm{a}$ \\
\hline APX activity & $0.30 \mathrm{~d}$ & $+3.3 \mathrm{~d}$ & $+6.7 \mathrm{~d}$ & $+6.7 \mathrm{~d}$ & $+70.6 \mathrm{c}$ & $+80.0 \mathrm{~b}$ & $+86.7 \mathrm{~b}$ & $+107 a$ \\
\hline GR activity & $0.34 \mathrm{~d}$ & $+5.9 \mathrm{~d}$ & $+2.9 \mathrm{~d}$ & $+5.9 \mathrm{~d}$ & $+46.7 \mathrm{c}$ & $+91.2 b$ & $+88.2 \mathrm{~b}$ & $+106 \mathrm{a}$ \\
\hline IAA content & $12.4 \mathrm{~b}$ & $+0.8 \mathrm{~b}$ & $+23.4 \mathrm{a}$ & $+25.0 \mathrm{a}$ & $-41.1 \mathrm{e}$ & $-30.6 d$ & $-16.1 \mathrm{c}$ & $+0.8 \mathrm{~b}$ \\
\hline $\mathrm{GA}_{1}$ content & $13.2 \mathrm{~b}$ & $+2.3 \mathrm{~b}$ & $+20.5 \mathrm{a}$ & $+20.5 \mathrm{a}$ & $-45.5 \mathrm{e}$ & $-30.3 d$ & $-14.4 \mathrm{c}$ & $0 \mathrm{~b}$ \\
\hline $\mathrm{GA}_{3}$ content & $16.7 \mathrm{~b}$ & $+1.2 \mathrm{~b}$ & $+15.0 \mathrm{a}$ & $+16.2 \mathrm{a}$ & $-47.9 \mathrm{e}$ & $-37.7 d$ & $-28.7 c$ & $-1.2 b$ \\
\hline T-Z content & $11.8 \mathrm{~b}$ & $+1.7 \mathrm{~b}$ & $+64.4 \mathrm{a}$ & $+67.8 \mathrm{a}$ & $-42.4 \mathrm{e}$ & $-28.8 d$ & $-14.4 \mathrm{c}$ & $+5.1 \mathrm{~b}$ \\
\hline SOD R. Exp. & $1.2 \mathrm{~d}$ & $0 \mathrm{~d}$ & $+8.3 \mathrm{~d}$ & $+8.3 \mathrm{~d}$ & $+192 \mathrm{c}$ & $+350 \mathrm{~b}$ & $+358 \mathrm{~b}$ & $+467 \mathrm{a}$ \\
\hline CAT R. Exp. & $1.2 \mathrm{~d}$ & $0 \mathrm{~d}$ & $0 \mathrm{~d}$ & $0 \mathrm{~d}$ & $+250 \mathrm{c}$ & $+417 \mathrm{~b}$ & $+433 b$ & $+533 a$ \\
\hline APX R. Exp. & $1.2 \mathrm{~d}$ & $+8.3 \mathrm{~d}$ & $+8.3 \mathrm{~d}$ & $+16.7 \mathrm{~d}$ & $+350 \mathrm{c}$ & $+492 \mathrm{~b}$ & $+508 \mathrm{~b}$ & $+600 \mathrm{a}$ \\
\hline GR R. Exp. & $1.2 \mathrm{~d}$ & $+16.7 \mathrm{~d}$ & $+16.7 \mathrm{~d}$ & $+16.7 \mathrm{~d}$ & $+392 \mathrm{c}$ & $+525 \mathrm{~b}$ & $+550 \mathrm{~b}$ & $+667 a$ \\
\hline PrxQ R. Exp. & $1.2 \mathrm{~d}$ & $0 \mathrm{~d}$ & $0 \mathrm{~d}$ & $0 \mathrm{~d}$ & $+442 \mathrm{c}$ & $+600 \mathrm{~b}$ & $+617 b$ & $+717 \mathrm{a}$ \\
\hline $\mathrm{Cd}^{2+}$ content & ND & ND & ND & ND & $+52.6 \mathrm{a}$ & $-43.3 b$ & $-40.3 b$ & $-78.3 c$ \\
\hline
\end{tabular}

Control = There is no stress and no foliar applications; $\mathrm{Sm}=$ foliar spray with $0.5 \mathrm{mM}$ silymarin; Meg = foliar spray with $2 \%$ maize grain extract; $\mathrm{MEg}-\mathrm{Sm}=$ foliar spray with maize grain extract enriched with silymarin $\left(0.24 \mathrm{~g} \mathrm{Sm} \mathrm{L}^{-1}\right.$ of $\left.\mathrm{MEg}\right)$; $\mathrm{Cd}=$ watering the maize seedlings with nourishing solution containing $0.5 \mathrm{mM} \mathrm{Cd} ; \mathrm{Cd}+\mathrm{Sm}=$ watering the maize seedlings with nourishing solution containing $0.5 \mathrm{mM} \mathrm{Cd}+$ foliar spray with $0.5 \mathrm{mM}$ silymarin; $\mathrm{Cd}+\mathrm{Meg}=$ watering the maize seedlings with nourishing solution containing $0.5 \mathrm{mM} \mathrm{Cd}+$ foliar spray with $2 \%$ maize grain extract; and Cd + MEg-Sm = watering the maize seedlings with nourishing solution containing $0.5 \mathrm{mM} \mathrm{Cd}+$ foliar spray with maize grain extract enriched with silymarin $\left(0.24 \mathrm{~g} \mathrm{Sm} \mathrm{L}^{-1} \mathrm{of} \mathrm{MEg}\right)$. FW = fresh weight; $\mathrm{DW}=$ dry weight; $\mathrm{iCE}=$ instantaneous carboxylation efficiency; Chl. = chlorophyll; Carot. = carotenoids; $\mathrm{O}_{2}{ }^{\bullet-}=$ superoxide radical; $\mathrm{H}_{2} \mathrm{O}_{2}$ = hydrogen peroxide; MDA = malondialdehyde; $\mathrm{EL}=$ ionic leakage; Pro = proline; AsA redox st. = ascorbate redox state; GSH redox st. = glutathione redox state; $\mathrm{Sm}=$ silymarin; $\mathrm{SOD}=$ superoxide dismutase; $\mathrm{CAT}=$ catalase; $\mathrm{APX}=$ ascorbate peroxidase; $\mathrm{GR}=$ glutathione reductase; $\mathrm{IAA}=$ inodole-3-acetic acid; $\mathrm{GA}_{1}=$ gibberellic acid $1 ; \mathrm{GA}_{3}=$ gibberellic acid 3; $\mathrm{T}-\mathrm{Z}=$ trans-zeatin; $\mathrm{R}$. Exp. = relative expression; $\mathrm{Cd}=$ cadmium.

The major mechanism in this regard, the observed increases in transcriptional levels of genes related to the examined antioxidant enzymes, had a major role in withstanding the adverse effects of stress $[8,50]$ in maize plants. In addition to these key mechanisms, increases in proline and Sm contents (Figure 3, Table 6) likely contributed to the increased defenses of the maize plant against $\mathrm{Cd}$ stress. Since many plant growth stimuli (e.g., AsA, $\mathrm{GSH}$, IAA, $\mathrm{GA}_{1}, \mathrm{GA}_{3}$, cytokinins including trans-zeatin, $\mathrm{SA}$, proline, and $\mathrm{Sm}$ ) are present in MEg-Sm (Table 5), which was the best treatment, it is considered a potent biostimulator to grow maize plants effectively under Cd stress (Figures 1-5, Table 6). 
Among the major growth stimulators present in MEg-Sm, proline, AsA, and GSH contents were greatly increased in Cd-stressed plants and contributed to stabilizing and maintaining cell membranes against stress damage [2,5,51-59]. These positive effects of these antioxidants might be attributed to their roles in minimizing the Cd content or other toxic elements and the levels of oxidative stress markers $\left(\mathrm{O}_{2}{ }^{\bullet-}\right.$ and $\mathrm{H}_{2} \mathrm{O}_{2}$; Figure 2, Table 6), thus minimizing lipid peroxidation in cell membranes. As a result of all these positive results, the photosynthetic efficiency including $F_{v} / F_{m}$ and iCE was maintained (Figure 1, Table 6) due to the integrity of cellular water content $[2,52,53,55]$. These positive results examined in this study were positively reflected in maize plant growth and dry matter accumulation (Figure 1, Table 6). Our findings are consistent with those in [2,5,51-59]. Restoration of growth and dry matter accumulation of $\mathrm{Cd}$-stressed maize plants are also due to the positive impacts of proline, AsA, and GSH present in MEg-Sm on increasing hormones (e.g., IAA, $\mathrm{GA}_{1}, \mathrm{GA}_{3}$, cytokinins including trans-zeatin, SA) content and homeostasis, which are necessary to restore the developmental growth of stressed plants [20,23,60-62].

Phytohormones play a large role in signaling, biochemistry, and defense pathways in plants, providing a key mechanism for relieving heavy metal stress [23,63]. The increased growth of Cd-stressed maize plants was likely related to the increased partitioning of photosynthesized substances with plant development and phytohormone levels (Figure 4, Table 6). Phytohormones regulate membrane permeability, enzyme activity, secondary metabolism, plant growth, and plant reproduction [23,64]. Elevated gibberellins (GAs) are shown in stressed plants to enhance stress tolerance by enhancing gene expression $[20,65,66]$. Thereafter, hormonal homeostasis under $\mathrm{Cd}$ stress could be a possible mechanism of GAs (e.g., $\mathrm{GA}_{1}$ and $\mathrm{GA}_{3}$ ) that stimulate $\mathrm{Cd}$ stress tolerance in the plant $[65,66]$. Cytokinins, including trans-Zeatin, and SA act to withstand stress. They play many regulatory roles in promoting plant growth, protein biosynthesis, and secondary metabolism $[61,62,66,67]$. They generally eliminate ROSs and increase the antigenicity of ABA under stress $[67,68]$. Another key phytohormone, IAA influences $\mathrm{Cd}$ toxicity, which has been relied upon to regulate many antioxidative activities, including the AsA-GSH cycle [68,69]. Altogether, phytohormones can raise antioxidant levels to reduce ROSs (e.g., $\mathrm{O}_{2}{ }^{\bullet-}$ and $\mathrm{H}_{2} \mathrm{O}_{2}$ ) levels, helping reduce lipid peroxidation (MDA) to keep healthy plant growth [49]. Phytohormones eliminate stressors' impacts and promote rates of survival $[70,71]$ by either enhancing shoot growth or regulating processes to prohibit plant growth (e.g., dormancy, withdrawal, and aging), and thus controlling growth activities in plants [72,73]. In our investigation, elevated hormonal content by MEg, Sm, or MEg-Sm (with a high preference for MEg-Sm) (Figure 4, Table 6) was associated with higher activity of the antioxidative defense system, antioxidant gene expression (Figures 3-5 and Table 6) and suppression in ROSs; $\mathrm{O}_{2}{ }^{--}$and $\mathrm{H}_{2} \mathrm{O}_{2}$ levels, which minimized MDA, EL, and Cd levels and maximized plant performance and photosynthesis efficiency (Figures 1 and 2, Table 6).

The induced activity of antioxidant enzymes that are premium biochemical signals of stress can eliminate $\mathrm{O}_{2}{ }^{\bullet-}$ and $\mathrm{H}_{2} \mathrm{O}_{2}$ stimulated by Cd. Despite elevated enzyme activity under $\mathrm{Cd}$ stress, spraying maize plants with $\mathrm{MEg}$, Sm, or MEg-Sm (with a high preference for MEg-Sm) further elevated SOD, CAT, APX, and GR activity while stimulating increased transcriptional levels of the antioxidant enzyme genes (Figures 4 and 5, Table 6). In this study, promotion of antioxidant gene transcript levels was associated with increased levels of proline, AsA, and GSH in contributing to increased enzymatic activities as a protective mechanism for suppressing many types of ROSs like $\mathrm{H}_{2} \mathrm{O}_{2},{ }^{1} \mathrm{O}_{2}, \mathrm{O}_{2}{ }^{\bullet-}, \mathrm{OH}^{-}$overproduced by stress. This positive finding contributed to keeping the metabolic processes to improve plant performance $[8,23,50-59]$. Given the diversity of the key bioactive ingredients present in MEg-Sm as a focal biostimulator (Table 5), it is a distinct strategy to treat maize plants as a foliar spray for the rapid growth of plants and efficient performance against Cd stress. A historical advance for controlling antioxidant genes for plant growth under stress has been reported by analyzing the transcriptional levels of antioxidant enzyme genes with the RT-qPCR technique $[8,50]$. Several enzyme genes are implicated in stressed plant development, and the molecular mechanisms of these antioxidant genes (e.g., SOD, CAT, 
APX, GR, and PrxQ) are linked with increased plant tolerance to stress [8,50]. In our study, along with the increase in nonenzymatic antioxidants, transcriptional levels of these genes increased under $\mathrm{Cd}$ stress and greatly increased with the application of $\mathrm{MEg}$-Sm to maize plants (Figure 5, Table 6). These positive findings were reflected in the increased activity of SOD, CAT, APX, and GR enzymes (Figure 4, Table 6) to enable maize plants to effectively withstand Cd stress, increase their photosynthesis efficiency, and thus growth and dry matter accumulation (Figure 1, Table 6).

The role of silymarin, $\mathrm{Sm}$ (present in the MEg-Sm), as a secondary metabolite ( $\mathrm{Sm}$ is a mixture of six flavonolignans (such as isosilybin A and B, silybin A and B, silydianin, and silychristin) and the flavonoid taxifolin), in improving plant performance under stress has not been achieved before. It has been reported that Sm can improve the productivity of plants since it accumulates in stressed plants to increase their defense systems [74,75]. This result is consistent with our results (Figure 3, Table 6). These reports [74,75] consider $\mathrm{Sm}$ as a powerful antioxidant, and thus its role in increasing plant resistance to stress is attributed to it as an antioxidant. Extensive studies are needed in this regard to exploring the precise mechanism of Sm for stress-tolerant plants.

The MEg-Sm results in this study are fully consistent with the characteristics of the biostimulator described by the European Biostimulant Industry Council [76] and with the findings of other work examining different stresses [3,20-23]. The growth promoters (bioactive compounds) present in MEg-Sm make it an effective biocatalyst and unique environmentally friendly strategy. MEg-Sm bioactive ingredients have functioned in this study to interplay with each other for successful plant growth under various stress conditions, including Cd stress. It has a high DPPH radical-scavenging activity $(89.22 \%)$ because of its richness in various antioxidants, which possess high states of redox. This makes MEg-Sm possess pivotal mechanisms to prevent or suppress ROSs and lipid peroxidation as explained above. The complex interplaying of the bioactive ingredients of MEg-Sm occurred, in this study, to confer a robust defensive system against $\mathrm{Cd}$-induced oxidative damage in favor of the performance of the maize plant.

The key ingredient biplot is a useful statistical method for assessing the interrelationship among the traits evaluated as well as the treatments examined [77,78]. In this study, the traits studied were divided into three groups. The traits exhibited a positive association with each other in the same group, whereas the traits with high positive values for PC1 displayed a negative association with those of negative PC1 values for PC1 $[79,80]$. Like the PC1, PC2 divided the treatments into two groups. The PC2 separated the applied treatments under $\mathrm{Cd}$ stress than those were performed under the absence of $\mathrm{Cd}$ on the other side of PC. Furthermore, the traits were identified in the first and third groups with treatments applied under $\mathrm{Cd}$ stress in the same sectors, indicating the importance of assessing these traits under $\mathrm{Cd}$ stress. These results are consistent with previous studies that showed the importance of physiological parameters as indicators under Cd stress [81-84].

\section{Conclusions}

The consequences of our study signalize an effective strategy of spraying Cd-stressed maize plants with MEg-Sm (bypassing MEg or Sm alone). This strategy can effectively promote plant growth and biomass accumulation. Enhancements of different attributes such as growth, photosynthesis efficiency, nonenzymatic antioxidants, antioxidant redox state, hormonal content and homeostasis, enzymatic antioxidants, and enzyme gene expression were focal aspects of foliar spraying of maize plants with MEg-Sm, which resulted in suppression of lipid peroxidation, ionic leakage, and oxidative damage catalyzed by ROSs $\left(\mathrm{O}_{2}{ }^{\bullet-}\right.$ and $\left.\mathrm{H}_{2} \mathrm{O}_{2}\right)$. These successful results were obtained as a result of the restriction of $\mathrm{Cd}$ ion accumulation and the activation of antioxidant defenses under $\mathrm{Cd}$ stress in maize plants. The interesting thing in our study is that MEg-Sm was more pronounced under $\mathrm{Cd}$ stress than normal conditions. The antioxidant and hormonal ingredients of MEg-Sm have functioned in our study as a natural biostimulant to interplay with each other in favor of Cd-stressed maize plants. Therefore, the findings of this study recommend the use of 
MEg-Sm as an effective novel biostimulator for Zea mays to promote various physiological and metabolic processes to boost $\mathrm{Cd}$ stress tolerance in maize plants. Extensive studies are needed in this regard to exploring the precise mechanism of Sm (in MEg-Sm) for stress-tolerant plants.

Supplementary Materials: The following are available online at https:/ / www.mdpi.com/2218-2 73X/11/3/465/s1, Table S1: A preliminary study conducted to assess the effect of cadmium (Cd), maize grain extract $(\mathrm{MEg})$, silymarin $(\mathrm{Sm})$, or silymarin-enriched maize grain extract $(\mathrm{MEg}-\mathrm{Sm})$ concentrations on some growth traits, instantaneous carboxylation efficiency (iCE), chlorophyll content, and trans-zeatin content of maize plants.

Author Contributions: Conceptualization, H.F.A., H.S.A.-Z., H.A., K.R.H., E.-S.M.D., and M.M.R.; data curation, H.F.A., H.S.A.-Z., K.R.H., E.-S.M.D., and M.M.R.; formal analysis, H.F.A., H.S.A.-Z., and M.M.R.; investigation, H.F.A., H.S.A.-Z., H.A., K.R.H., and M.M.R.; methodology, H.F.A., H.S.A.Z., H.A., and M.M.R.; resources, H.F.A., H.S.A.-Z., H.A., K.R.H., E.-S.M.D., and M.M.R.; software, H.F.A., H.S.A.-Z., H.A., and M.M.R.; writing-original draft, H.F.A., H.S.A.-Z., K.R.H., E.-S.M.D., and M.M.R.; writing-review and editing, H.F.A., H.S.A.-Z., H.A., K.R.H., E.-S.M.D., and M.M.R. All authors have read and agreed to the published version of the manuscript.

Funding: This research was funded by the Deanship of Scientific Research (DSR) at King Abdulaziz University, grant number RG-1-130-40 and The APC was funded by the Deanship of Scientific Research (DSR) at King Abdulaziz University.

Institutional Review Board Statement: Not applicable.

Informed Consent Statement: Not applicable.

Data Availability Statement: The data presented in this study are available upon request from the corresponding author.

Acknowledgments: This project was funded by the Deanship of Scientific Research (DSR) at King Abdulaziz University, Jeddah, under grant no. (RG-1-130-40). The authors, therefore, acknowledge with thanks DSR for technical and financial support.

Conflicts of Interest: The authors declare no conflict of interest.

\section{References}

1. Alzahrani, Y.; Kuşvuran, A.; Alharby, H.F.; Kuşvuran, S.; Rady, M.M. The defensive role of silicon in wheat against stress conditions induced by drought, salinity or cadmium. Ecotoxicol. Environ. Saf. 2018, 154, 187-196. [CrossRef] [PubMed]

2. Semida, W.M.; Hemida, K.A.; Rady, M.M. Sequenced ascorbate-proline-glutathione seed treatment elevates cadmium tolerance in cucumber transplants. Ecotoxicol. Environ. Saf. 2018, 154, 171-179. [CrossRef] [PubMed]

3. Alzahrani, Y.; Rady, M.M. Compared to antioxidants and polyamines, the role of maize grain-derived organic bi-ostimulants in improving cadmium tolerance in wheat plants. Ecotoxicol. Environ. Saf. 2019, 182, 109378. [CrossRef] [PubMed]

4. Desoky, E.M.; Elrys, A.S.; Rady, M.M. Integrative Moringa and Licorice extracts application improves performance and reduces fruit contamination content of pepper plants grown on heavy metals-contaminated saline soil. Ecotoxicol. Environ. Saf. 2019, 169, 50-60. [CrossRef]

5. Rady, M.M.; Elrys, E.S.; Abo El-Maati, M.E.; Desoky, E.M. Interplaying roles of silicon and proline effectively improve salt and cadmium stress tolerance in Phaseolus vulgaris plant. Plant Physiol. Biochem. 2019, 139, 558-568. [CrossRef]

6. Taie, H.A.A.; El-Yazal, M.A.S.; Ahmed, S.M.A.; Rady, M.M. Polyamines modulate growth, antioxidant activity, and genomic DNA in heavy metal-stressed wheat plant. Environ. Sci. Pollut. Res. 2019, 26, 22338-22350. [CrossRef]

7. Desoky, E.M.; Merwad, A.M.; Semida, W.M.; Ibrahim, S.A.; El-Saadony, M.T.; Rady, M.M. Heavy Metals-Resistant Bac-teria (HM-RB): Potential bioremediators for heavy metals-stressed spinach plants. Ecotoxicol. Environ. Saf. 2020, 198, 110685. [CrossRef]

8. Imran, M.; Hussain, S.; El-Esawi, M.A.; Rana, M.S.; Saleem, M.H.; Riaz, M.; Ashraf, U.; Potcho, M.P.; Duan, M.; Rajput, I.A.; et al. Molybdenum Supply Alleviates the Cadmium Toxicity in Fragrant Rice by Modulating Oxidative Stress and Antioxidant Gene Expression. Biomology 2020, 10, 1582. [CrossRef] [PubMed]

9. Shanying, H.; Xiaoe, Y.; Zhenli, H.; Baligar, V.C. Morphological and physiological responses of plants to cadmium toxicity: A review. Pedosphere 2017, 27, 421-438.

10. Sarwar, N.; Ishaq, W.; Farid, G.; Shaheen, M.R.; Imran, M.; Geng, M.; Hussain, S. Zinc-cadmium interactions: Impact on wheat physiology and mineral acquisition. Ecotoxicol. Environ. Saf. 2015, 122, 528-536. [CrossRef]

11. Hussain, S.; Khaliq, A.; Noor, M.A.; Tanveer, M.; Hussain, H.A.; Shah, T.; Mehmood, T. Metal Toxicity and Nitrogen Metabolism in Plants: An Overview. In Carbon and Nitrogen Cycling in Soil; Springer International Publishing: Berlin, Germany, 2020; pp. 221-248. 
12. Hussain, S.; Khan, F.; Cao, W.; Wu, L.; Geng, M. Seed priming alters the production and detoxification of reactive ox-ygen intermediates in rice seedlings grown under sub-optimal temperature and nutrient supply. Front. Plant Sci. 2016, 7, 439. [CrossRef]

13. Kevrešan, S.; Petrović, N.; Popovic, M.; Kandrač, J. Nitrogen and Protein Metabolism in Young Pea Plants as Affected by Different Concentrations of Nickel, Cadmium, Lead, and Molybdenum. J. Plant Nutr. 2001, 24, 1633-1644. [CrossRef]

14. Cao, F.; Wang, R.; Cheng, W.; Zeng, F.; Ahmed, I.M.; Hu, X.; Zhang, G.; Wu, F. Genotypic and environmental variation in cadmium, chromium, lead and copper in rice and approaches for reducing the accumulation. Sci. Total Environ. 2014, 496, 275-281. [CrossRef] [PubMed]

15. Grant, C.; Clarke, J.; Duguid, S.; Chaney, R. Selection and breeding of plant cultivars to minimize cadmium accumu-lation. Sci. Total Environ. 2008, 390, 301-310. [CrossRef] [PubMed]

16. Uraguchi, S.; Mori, S.; Kuramata, M.; Kawasaki, A.; Arao, T.; Ishikawa, S. Root-to-shoot Cd translocation via the xy-lem is the major process determining shoot and grain cadmium accumulation in rice. J. Exp. Bot. 2009, 60, 2677-2688. [CrossRef] [PubMed]

17. Bertoli, A.C.; Cannata, M.G.; Carvalho, R.; Bastos, A.R.R.; Freitas, M.P.; dos Santos Augusto, A. Lycopersicon escu-lentum submitted to Cd-stressful conditions in nutrition solution: Nutrient contents and translocation. Ecotoxicol. Environ. Saf. 2012, 86, 176-181. [CrossRef]

18. Khan, A.; Khan, S.; Alam, M.; Khan, M.A.; Aamir, M.; Qamar, Z.; Rehman, Z.U.; Perveen, S. Toxic metal interactions affect the bioaccumulation and dietary intake of macro- and micro-nutrients. Chemosphere 2016, 146, 121-128. [CrossRef]

19. Ismael, M.A.; Elyamine, A.M.; Zhao, Y.Y.; Moussa, M.G.; Rana, M.S.; Afzal, J.; Imran, M.; Zhao, X.H.; Hu, C.X. Can Selenium and Molybdenum Restrain Cadmium Toxicity to Pollen Grains in Brassica napus? Int. J. Mol. Sci. 2018, 19, 2163. [CrossRef] [PubMed]

20. Semida, W.M.; Rady, M.M. Presoaking application of propolis and maize grain extracts alleviates salinity stress in common bean (Phaseolus vulgaris L.). Sci. Hortic. 2014, 168, 210-217. [CrossRef]

21. Rady, M.M.; Talaat, N.B.; Abdelhamid, M.T.; Shawky, B.T.; Desoky, E.-S.M. Maize (Zea mays L.) grains extract mitigates the deleterious effects of salt stress on common bean (Phaseolus vulgaris L.) growth and physiology. J. Hortic. Sci. Biotechnol. 2019, 94, 777-789. [CrossRef]

22. Rehman, H.U.; Alharby, H.F.; Alzahrani, Y.; Rady, M.M. Magnesium and organic biostimulant integrative application induces physiological and biochemical changes in sunflower plants and its harvested progeny on sandy soil. Plant Physiol. Biochem. 2018, 126, 97-105. [CrossRef]

23. Alharby, H.F.; Alzahrani, Y.N.; Rady, M.M. Seeds pretreatment with zeatins or maize grain-derived organic biostim-ulant improved hormonal contents, polyamine gene expression, and salinity and drought tolerance of wheat. Int. J. Agric. Biol. 2020 24, 714-724.

24. Pál, M.; Horváth, E.; Janda, T.; Páldi, E.; Szalai, G. Physiological changes and defense mechanisms induced by cad-mium stress in maize. J. Plant Nutr. Soil Sci. 2006, 169, 239-246. [CrossRef]

25. Badr, R. Molecular and Physiological Responses of Maize and Wheat Plants After Exposure to Some Abiotic Environ-Mental Stresses. Ph.D. Dissertation, Faculty of science, Alexandria University, Alexandria, Egypt, 2014.

26. Gajdos, É.; Lévai, L.; Veres, S.; Kovács, B. Effects of Biofertilizers on Maize and Sunflower Seedlings under Cadmium Stress. Commun. Soil Sci. Plant Anal. 2012, 43, 272-279. [CrossRef]

27. Bates, L.S.; Waldren, R.P.; Teare, I.D. Rapid determination of free proline for water-stress studies. Plant Soil 1973, 39, 205-207. [CrossRef]

28. Kampfenkel, K.; Van Montagu, M. Extraction and determination of ascorbate and dehydroascorbate from plant tis-sue. Anal. Biochem. 1995, 225, 165-167. [CrossRef] [PubMed]

29. Griffth, O.W. Determination of glutathione and glutathione disulfide using glutathione reductase and 2 vinyl pyri-dine. Anal. Biochem. 1980, 106, 207-212. [CrossRef]

30. Arampatzis, D.A.; Karkanis, A.C.; Tsiropoulos, N.G. Silymarin content and antioxidant activity of seeds of wild Si-lybum marianum populations growing in Greece. Ann. Appl. Biol. 2019, 174, 61-73. [CrossRef]

31. Arampatzis, D.A.; Karkanis, A.C.; Tsiropoulos, N.G. Impact of Plant Density and Mepiquat Chloride on Growth, Yield, and Silymarin Content of Silybum marianum Grown under Mediterranean Semi-Arid Conditions. Agronomy 2019, 9, 669. [CrossRef]

32. Lee, S.C.; Kim, J.H.; Jeong, S.M.; Kim, D.R.; Ha, J.U.; Nam, K.C. Effect of far-infrared radiation on the antioxidant activ-ity of rice hulls. J. Agric. Food Chem. 2003, 51, 4400-4403. [CrossRef]

33. Terra, L.A.; Soares, C.P.; Meneses, C.H.S.G.; Sfeir, T.Z.M.; Souza, E.M.; Silveira, V.; Vidal, S.M.; Baldani, J.I.; Schwab, S. Transcriptome and proteome profiles of the diazotroph Nitrospirillum amazonense strain CBAmC in response to the sugarcane apoplast fluid. Plant Soil. 2020, 451, 145-168. [CrossRef]

34. Konrad, M.L.F.; Silva, J.A.B.; Furlani, P.R.; Machado, E.C. Trocas gasosas e fluorescência da clorofila em seis culti-vares de cafeeiro sob estresse de alumínio. Bragantia 2005, 64, 30-37. [CrossRef]

35. Wellburn, A.R. The spectral determination of chlorophylls a and $b$, as well as total Carotenoids, using various sol-vents with spectrophotometers of different resolution. J. Plant Physiol. 1994, 144, 307-313. [CrossRef]

36. Avron, M. Photophosphorylation by swiss-chard chloroplasts. Biochim. Biophys. Acta BBA-Ioenerg. 1960, 40, 257-272. [CrossRef]

37. Kubiś, J. Exogenous spermidine differentially alters activities of some scavenging system enzymes, $\mathrm{H} 2 \mathrm{O} 2$ and superoxide radical levels in water-stressed cucumber leaves. J. Plant Physiol. 2008, 165, 397-406. [CrossRef] 
38. Velikova, V.; Yordanov, I.; Edreva, A. Oxidative stress and some antioxidant systems in acid rain-treated bean plants. Plant Sci. 2000, 151, 59-66. [CrossRef]

39. Heath, R.L.; Packer, L. Photo peroxidation isolated chloroplasts: Kinetics and stoichiometry of fatty acid peroxida-tion. Arch. Biochem. Biophys. 1968, 125, 189-198. [CrossRef]

40. Rady, M.M. Effect of 24-epibrassinolide on growth, yield, antioxidant system and cadmium content of bean (Phaseolus vulgaris L.) plants under salinity and cadmium stress. Sci. Hortic. 2011, 129, 232-237. [CrossRef]

41. Chapman, H.D.; Pratt, P.F. Methods of Analysis for Soils, Plants and Waters. Soil Sci. 1962, 93, 68. [CrossRef]

42. Bradford, M.M. A rapid and sensitive method for the quantitation of microgram quantities of protein utilizing the principle of protein-dye binding. Anal. Biochem. 1976, 72, 248-254. [CrossRef]

43. Kono, Y. Generation of superoxide radical during autoxidation of hydroxylamine and an assay for superoxide dis-mutase. Arch. Biochem. Biophys. 1978, 186, 189-195. [CrossRef]

44. Aebi, H. Catalase in vitro. Methods Enzymol. 1984, 105, 121-126. [PubMed]

45. Rao, M.V.; Paliyath, G.; Ormrod, P. Ultraviolet-9- and Ozone-lnduced Biochemical Changes in Antioxidant Enzymes of Arabidopsis thaliana. Plant Physiol. 1996, 110, 125-136. [CrossRef]

46. Ruijter, J.M.; Ramakers, C.; Hoogaars, W.M.H.; Karlen, Y.; Bakker, O.; Hoff, M.J.B.V.D.; Moorman, A.F.M. Amplification efficiency: Linking baseline and bias in the analysis of quantitative PCR data. Nucleic Acids Res. 2009, 37, e45. [CrossRef]

47. Pfaffl, M.W. A new mathematical model for relative quantification in real-time RT-PCR. Nucleic Acids Res. 2001, 29, e45. [CrossRef] [PubMed]

48. Steel, R.G.D.; Torrie, J.H.; Dicky, D.A. Principles and Procedures of Statistics: A Biometrical Approach, 3rd ed.; McGraw-Hill, International Book Co.: New York, NY, USA, 1997; pp. 352-358.

49. Sytar, O.; Kumari, P.; Yadav, S.; Brestic, M.; Rastogi, A. Phytohormone Priming: Regulator for Heavy Metal Stress in Plants. J. Plant Growth Regul. 2019, 38, 739-752. [CrossRef]

50. Desoky, E.-S.M.; ElSayed, A.I.; Merwad, A.-R.M.A.; Rady, M.M. Stimulating antioxidant defenses, antioxidant gene expression, and salt tolerance in Pisum sativum seedling by pretreatment using licorice root extract (LRE) as an organ-ic biostimulant. Plant Physiol. Biochem. 2019, 142, 292-302. [CrossRef]

51. Rady, M.M.; Hemida, Kh.A. Sequenced application of ascorbate-proline-glutathione improves salt tolerance in maize seedlings. Ecotoxicol. Environ. Saf. 2016, 133, 252-259. [CrossRef]

52. Rady, M.M.; Taha, R.S.; Mahdi, A.H.A. Proline enhances growth, productivity and anatomy of two varieties of Lupi-nus termis L. grown under salt stress. S. Afr. J. Bot. 2016, 102, 221-227. [CrossRef]

53. Merwad, A.M.A.; Desoky, E.M.; Rady, M.M. Drought-stressed Vigna unguiculata growth, yield, water use efficiency, physiobiochemical attributes and anatomy responses to silicon, proline or methionine foliar application. Sci. Hortic. 2018, 228, 132-144. [CrossRef]

54. Abdel-Hafeez, A.N.A.; El-Mageed, T.A.A.; Rady, M.M. Impact of Ascorbic Acid Foliar Spray and Seed Treatment with Cyanobacteria on Growth and Yield Component of Sunflower Plants under Saline Soil Conditions. Int. Lett. Nat. Sci. 2019, 76, 136-146. [CrossRef]

55. Rady, M.M.; Kuşvuran, A.; Alharby, H.F.; Alzahrani, Y.; Kuşvuran, S. Pretreatment with proline or an organic bio-stimulant induces salt tolerance in wheat plants by improving antioxidant redox state and enzymatic activities and reducing the oxidative stress. J. Plant Growth Regul. 2019, 38, 449-462. [CrossRef]

56. Zaki, S.S.; Belal, E.E.; Rady, M.M. Cyanobacteria and Glutathione Applications Improve Productivity, Nutrient Contents, and Antioxidant Systems of Salt-Stressed Soybean Plant. Int. Lett. Nat. Sci. 2019, 76, 72-85. [CrossRef]

57. Al-Elwany, O.A.; Mohamed, G.F.; Abdehrahman, H.A.; Rady, M.M.; Abdel Latef, A.H. Exogenous glutathi-one-mediated tolerance to deficit irrigation stress in salt-affected Capsicum frutescence (L.) plants is connected with higher antioxidant content and proper ion homeostasis. Not. Bot. Horti Agrobot. Cluj Napoca. 2020, 48, 1957-1979. [CrossRef]

58. Desoky, E.-S.M.; Mansour, E.; Yasin, M.A.T.; El-Sobky, E.-S.E.A.; Rady, M.M. Improvement of drought tolerance in five different cultivars of Vicia faba with foliar application of ascorbic acid or silicon. Span. J. Agric. Res. 2020, 18, e0802. [CrossRef]

59. Rehman, H.U.; Alharby, H.F.; Bamagoos, A.A.; Abdelhamid, M.T.; Rady, M.M. Sequenced application of glutathione as an antioxidant with an organic biostimulant improves physiological and metabolic adaptation to salinity in wheat. Plant Physiol. Biochem. 2021, 158, 43-52. [CrossRef]

60. Rady, M.M.; Mohamed, G.F. Modulation of salt stress effects on the growth, physio-chemical attributes and yields of Phaseolus vulgaris L. plants by the combined application of salicylic acid and Moringa oleifera leaf extract. Sci. Hortic. 2015, 193, 105-113. [CrossRef]

61. Semida, W.M.; Rady, M.M. Pre-soaking in 24-epibrassinolide or salicylic acid improves seed germination, seedling growth, and anti-oxidant capacity in Phaseolus vulgaris L. grown under $\mathrm{NaCl}$ stress. J. Hortic. Sci. Biotechnol. 2014, 89, 338-344. [CrossRef]

62. Semida, W.M.; Rady, M.M.; Abd El-Mageed, T.A.; Howladar, S.M.; Abdelhamid, M.T. Alleviation of cadmium toxicity in common bean (Phaseolus vulgaris L.) plants by the exogenous application of salicylic acid. J. Hortic. Sci. Biotechnol. 2015, 90, 83-91.

63. Bücker-Neto, L.; Paiva, A.L.S.; Machado, R.D.; Arenhart, R.A.; Margis-Pinheiro, M. Interactions between plant hor-mones and HMs responses. Genet. Mol. Biol. 2017, 40, 373-386. [CrossRef] [PubMed]

64. Wani, S.H.; Kumar, V.; Shriram, V.; Sahd, S.K. Phytohormones and their metabolic engineering for abiotic stress tol-erance in crop plants. Crop J. 2016, 4, 162-176. [CrossRef] 
65. He, Y.; Li, W.; Lv, J.; Jia, Y.; Wang, M.; Xia, G. Ectopic expression of a wheat MYB transcription factor gene, TaMYB73, improves salinity stress tolerance in Arabidopsis thaliana. J. Exp. Bot. 2011, 63, 1511-1522. [CrossRef]

66. Verma, V.; Ravindran, P.; Kumar, P.P. Plant hormone-mediated regulation of stress responses-A review. BMC Plant Biol. 2016, 16, 86. [CrossRef]

67. Pospisilova, J. Interaction of Cytokinins and Abscisic Acid During Regulation of Stomatal Opening in Bean Leaves. Photosynth 2003, 41, 49-56. [CrossRef]

68. Chakrabarti, N.; Mukherji, S. Alleviation of NaCl Stress by Pretreatment with Phytohormones in Vigna radiata. Biol. Plant. 2003, 46, 589-594. [CrossRef]

69. Bashri, G.; Prasad, S.M. Indole acetic acid modulates changes in growth, chlorophyll a fluorescence and anti-oxidant potential of Trigonella foenum-graecum L. grown under cadmium stress. Acta Physiol. Plant. 2015, 37, 1745. [CrossRef]

70. Fahad, S.; Hussain, S.; Bano, A.; Saud, S.; Hassan, S.; Shan, D.; Khan, F.A.; Khan, F.; Chen, Y.; Wu, C. Potential role of phytohormones and plant growth-promoting rhizobacteria in abiotic stresses: Consequences for changing environ-ment. Environ. Sci. Pollut. Res. 2015, 22, 4907-4921. [CrossRef] [PubMed]

71. Ahmed, A.; Hasnain, S. Auxins as one of the factors of plant growth improvement by plant growth promoting rhizo-bacteria. Pol. J. Microbiol. 2014, 63, 261-266. [CrossRef] [PubMed]

72. Wu, H.-M.; Hazak, O.; Cheung, A.Y.; Yalovsky, S. RAC/ROP GTPases and Auxin Signaling. Plant Cell 2011, $23,1208-1218$. [CrossRef] [PubMed]

73. Parray, J.A.; Jan, S.; Kamili, A.N.; Qadri, R.A.; Egamberdieva, D.; Ahmad, P. Current Perspectives on Plant Growth-Promoting Rhizobacteria. J. Plant Growth Regul. 2016, 35, 877-902. [CrossRef]

74. Ghavami, N.; Ramin, A.A. Grain Yield and Active Substances of Milk Thistle as Affected by Soil Salinity. Commun. Soil Sci. Plant Anal. 2008, 39, 2608-2618. [CrossRef]

75. Afshar, R.K.; Chaichi, M.R.; Jovini, M.A.; Jahanzad, E.; Hashemi, M. Accumulation of silymarin in milk thistle seeds under drought stress. Planta 2015, 242, 539-543. [CrossRef]

76. Colla, G.; Rouphael, Y. Biostimulants in horticulture. Sci. Hortic. 2015, 196, 1-2. [CrossRef]

77. Mansour, E.; Moustafa, E.S.; Desoky, E.-S.M.; Ali, M.; Yasin, M.A.; Attia, A.; Alsuhaibani, N.; Tahir, M.U.; El-Hendawy, S. Multidimensional evaluation for detecting salt tolerance of bread wheat genotypes under actual saline field growing conditions. Plants 2020, 9, 1324. [CrossRef] [PubMed]

78. Moustafa, E.S.; Ali, M.; Kamara, M.M.; Awad, M.F.; Hassanin, A.A.; Mansour, E. Field Screening of Wheat Advanced Lines for Salinity Tolerance. Agronomy 2021, 11, 281. [CrossRef]

79. Mansour, E.; Desoky, E.M.; Ali, M.M.A.; Abdul-Hamid, M.I.; Ullah, H.; Attia, A.; Datta, A. Identifying drought-tolerant genotypes of faba bean and their agro-physiological responses to different water regimes in an arid Mediterranean environment. Agric. Water Manag. 2021, 247, 106754. [CrossRef]

80. Desoky, E.-S.M.; Mansour, E.; Ali, M.M.A.; Yasin, M.A.T.; Abdul-Hamid, M.I.E.; Rady, M.M.; Ali, E.F. Exogenously Used 24-Epibrassinolide Promotes Drought Tolerance in Maize Hybrids by Improving Plant and Water Productivity in an Arid Environment. Plants 2021, 10, 354. [CrossRef]

81. Molnárová, M.; Fargašová, A. Relationship between various physiological and biochemical parameters activated by cadmium in Sinapis alba L. and Hordeum vulgare L. Ecol. Eng. 2012, 49, 65-72. [CrossRef]

82. Xu, D.; Chen, Z.; Sun, K.; Yan, D.; Kang, M.; Zhao, Y. Effect of cadmium on the physiological parameters and the subcellular cadmium localization in the potato (Solanum tuberosum L.). Ecotoxicol. Environ. Saf. 2013, 97, 147-153. [CrossRef]

83. Ling, T.; Gao, Q.; Du, H.; Zhao, Q.; Ren, J. Growing, physiological responses and Cd uptake of Corn (Zea mays L.) under different Cd supply. Chem. Spec. Bioavailab. 2017, 29, 216-221. [CrossRef]

84. Liu, Y.; Yu, X.; Feng, Y.; Zhang, C.; Wang, C.; Zeng, J.; Huang, Z.; Kang, H.; Fan, X.; Sha, L. Physiological and transcriptome response to cadmium in cosmos (Cosmos bipinnatus Cav.) seedlings. Sci. Rep. 2017, 7, 1-16. [CrossRef] [PubMed] 